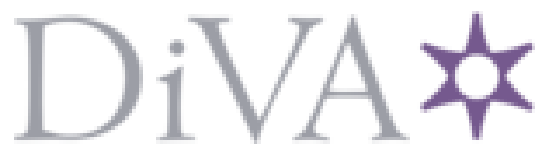

http://www.diva-portal.org

This is the published version of a paper published in .

Citation for the original published paper (version of record):

Quino Lima, I., Ormachea Muñoz, M., Ramos Ramos, O E., Bhattacharya, P., Quispe Choque, R. et al. (2019)

Hydrochemical assessment with respect to arsenic and other trace elementsin the Lower Katari Basin, Bolivian Altiplano

Groundwater for Sustainable Development, : 281-293

https://doi.org/10.1016/j.gsd.2018.11.013

Access to the published version may require subscription.

N.B. When citing this work, cite the original published paper.

Permanent link to this version:

http://urn.kb.se/resolve?urn=urn:nbn:se:kth:diva-273372 


\title{
Hydrochemical assessment with respect to arsenic and other trace elements in the Lower Katari Basin, Bolivian Altiplano
}

\author{
Israel Quino Lima ${ }^{\mathrm{a}, \mathrm{b}, *}$, Mauricio Ormachea Muñoz ${ }^{\mathrm{a}}$, Oswaldo Eduardo Ramos Ramos ${ }^{\mathrm{a}}$, \\ Prosun Bhattacharya ${ }^{b}$, Raul Quispe Choque ${ }^{\mathrm{a}}$, Jorge Quintanilla Aguirre ${ }^{\mathrm{a}}$, Ondra Sracek ${ }^{\mathrm{c}}$ \\ ${ }^{a}$ Laboratorio de Hidroquímica, Instituto de Investigaciones Químicas (IIQ), Universidad Mayor de San Andrés, Campus Universitario (UMSA), Cota Cota 27, PO. Box 303, \\ La Paz, Bolivia \\ ${ }^{\mathrm{b}}$ KTH-International Arsenic Research Group, Department of Sustainable Development, Environmental Science and Engineering, KTH Royal Institute of Technology, \\ Teknikringen 10B, SE-100 44 Stockholm, Sweden \\ ${ }^{\mathrm{c}}$ Department of Geology, Faculty of Science, Palacky' University, 17. listopadu 12, 77146 Olomouc, Czech Republic
}

\section{A B S T R A C T}

Hydrochemical investigations of groundwater and surface water were carried out to better understand the spatial distribution of As, major ions and trace elements. The study was carried out to evaluate the sources of dissolved species and elucidate the processes that govern the evolution of natural water in the Lower Katari Basin. The study area is close to the Titicaca Lake (Cohana Bay) formed by sediments of the Quaternary system, deposited in the fluvio-glacial to fluvio-lacustrine environment and geologic formations of the Devonian and Neogene system of volcanic origin. The study area has several environmental problems mainly caused by contaminants such as heavy metals, nutrients, and bacteria. These problems are linked to the urban and industrial wastes, natural geologic conditions, and mining activities carried out upstream of the Katari Basin, where rivers discharge into the Cohana Bay.

A total of 37 water samples were collected during wet season, 31 groundwater samples including drinking water wells and six surface water samples. The hierarchical cluster analysis and principal component analysis were applied to hydrochemical data. Results show high salinity in groundwater related to the evaporation causing serious problems for the groundwater quality and rendering it unsuitable for drinking. Dissolved As concentration ranges from 0.7 to $89.7 \mu \mathrm{g} / \mathrm{L}$; the principal source of As could be the alteration of volcanic rocks, more than $48 \%$ of the shallow groundwater samples exceeded the WHO guideline value for As and more than $22 \%$ for $\mathrm{NO}_{3}{ }^{-}$. Groundwater has neutral to slightly alkaline $\mathrm{pH}$, and moderately oxidizing character. The groundwater chemistry reveals considerable variability, ranging from $\mathrm{Na}-\mathrm{SO}_{4}, \mathrm{Cl}$ type through mixed $\mathrm{Na}-\mathrm{HCO}_{3}$ type and $\mathrm{Ca}, \mathrm{Na}-\mathrm{HCO} \mathrm{O}_{3}, \mathrm{Cl}$ type. The distribution of trace elements shows a large range of concentrations. Speciation of As indicates that the predominant oxidation state is As (V). The geochemical modelling indicates that As could be associated with iron oxides and hydroxides which are probably the most important mineral phases for the As adsorption. The spatial distribution and the variation of dissolved As concentration in groundwater is governed by the variability in geological characteristics of the region that raises a significant concern about drinking water quality.

\section{Introduction}

The TDPS system (Titicaca - Desaguadero - Poopó - Salar of Coipasa) is an endoreic basin (Peruvian and Bolivian Altiplano), comprising the Basin of Titicaca Lake, Desaguadero River, Poopó Lake and Coipasa Salt flat. It is located between Eastern and Western Cordillera from 3600 and $4500 \mathrm{~m}$ a.s.l. (above sea level; ORSTOM, 1991); the area of the TDPS System (Fig. 1a) is of $143,900 \mathrm{~km}^{2}$ (ALT, 2017). The Titicaca Lake is the main regulatory element of the system and has an area of $8400 \mathrm{~km}^{2}$ (ALT, 2017), is the highest navigable lake in the world (3810 $\mathrm{m}$ a.s.l. average altitude) (Martinez et al., 2004). The Titicaca Lake is divided into two basins, the major lake "Chucuito" (Titicaca Major Lake; $135 \mathrm{~m}$ mean depth) and minor lake "Huiñaimarca" (Titicaca Minor Lake; 9 m mean depth) (ORSTOM, 1991; ALT, 2005).

The Titicaca Minor Lake has been impacted by heavy metals, nutrient elements and microbial inputs which reach the Cohana Bay (Ribera, 2010). The Cohana Bay (5-10 m, depth) (ORSTOM, 1991) is considered as the most contaminated site of the Bolivian part of the Titicaca Minor Lake (Ribera, 2008). These problems were caused probably due to the discharge of the urban and industrial wastewater from El Alto and Viacha cities without proper treatment as well as the discharges from the areas of intense mining activities in the region of Milluni (El Alto) upstream of Katari Basin (Fig. 1b). The pollutants are transported by Seque (located at upstream of the basin), Seco and Pallina rivers which are connected to the Cohana Bay through the Katari River (Fig. 1c).

Salvarredy-Aranguren et al., (2008) found that the surface water (SW) quality in the Katari Basin is greatly affected by the mining activities in the Milluni Valley located in the north of the Katari Basin. There are high concentrations of metals (Cd, $\mathrm{Zn}, \mathrm{As}, \mathrm{Cu}, \mathrm{Ni}, \mathrm{Pb}$ and $\mathrm{Sn}$ )

\footnotetext{
* Corresponding author.

E-mail address: israelql@kth.se (I.Q. Lima).
} 


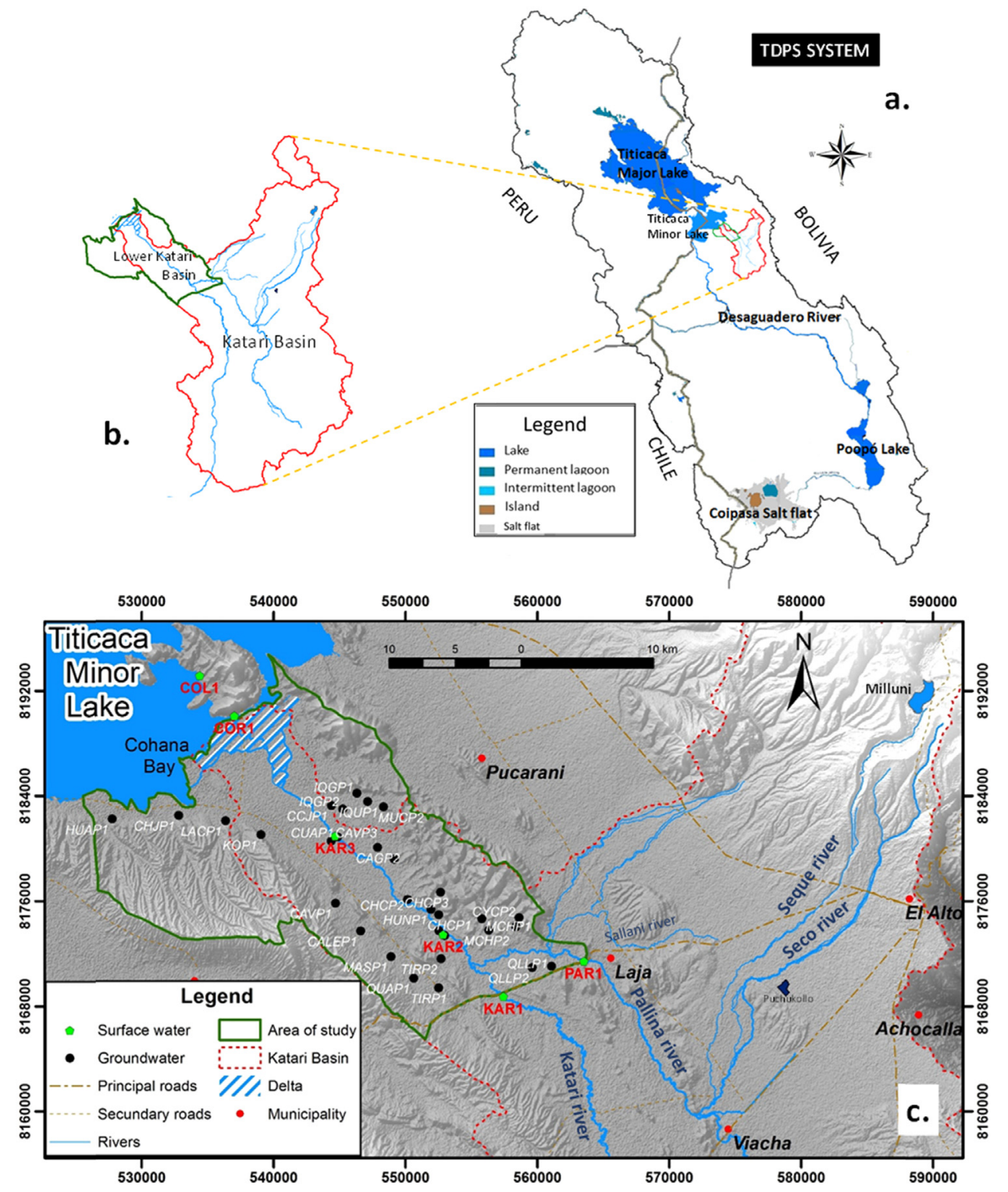

Fig. 1. Map of the Titicaca - Desaguadero - Poopó - Salt flat of Coipasa (TDPS system) (a), Katari Basin (b) and study area and sampling points (c).

that exceed the World Health Organization (WHO) water guidelines for human consumption.

The wastewater in the river systems of the urban area show high concentrations of As and phosphate $\left(\mathrm{PO}_{4}{ }^{3-}\right)$ exceeding both national and WHO guideline for As (10 $\mu \mathrm{g} / \mathrm{L}, \mathrm{NB}-512,(10 \mu \mathrm{g} / \mathrm{LWHO}, 2011)$ and the European guidelines for highly polluted river waters for $\mathrm{PO}_{4}{ }^{3-}$ $(2 \mathrm{mg} / \mathrm{L})$ (Duwig et al., 2014). Both mining activities and urban areas have an impact on the basin from the mining area upstream to Cohana Bay (Archundia et al., 2017).

The demands for water in urban centers (El Alto, Viacha and Laja) are increasing while many small communities lack of adequate water and sanitation services (Lower Katari Basin). The rural areas with great agricultural potential are severely impacted due to quanty and quality of water (MMAyA, 2010). El Alto and Viacha are the most important cities in the study area, with more than 848,840 and 80,388 habitants, respectively (INE, 2017). Around the area there are predominantly agricultural activities (Laja and Pucarani towns).

The aquatic pollution has been extensively studied in the central and northeastern part of the Katari Basin during the last decade (Chudnoff, 2006; Salvarredy-Aranguren et al., 2008) and in recent years (MMAyA, 2010; IISIIS, 2013; Duwig et al., 2014; Chiron and
Duwig, 2016; Archundia et al., 2016, 2017), taking into account hydrological, physicochemical, chemical and microbiological data, However, dynamics and sources of As and trace elements (TEs) in the shallow and deep groundwater (GW) of the Lower Katari Basin have not been investigated so far. The present study was designed to characterize the geochemistry of GW and SW, to evaluate the sources of dissolved species, and to elucidate the processes that govern the evolution of water chemistry in the Lower Katari Basin near the Cohana Bay (Titicaca Minor Lake).

\section{Study area}

\subsection{General description}

The study area is located in the southeastern part of the Titicaca Minor Lake, within the Katari Basin in the Bolivian Altiplano, includes the entire Lower Katari Basin and is a part of the Cohana Bay with an area of $484 \mathrm{~km}^{2}$, with an elevation range between 3610 to $4200 \mathrm{~m}$ a.s.l. (Fig. 1c). According to the 2012 census the area had 18,674 inhabitants (INE, 2017). The main crops in the areas bordering the lake are many varieties of potato, quinoa, barley, sweet potato, bean, pea, and alfalfa 


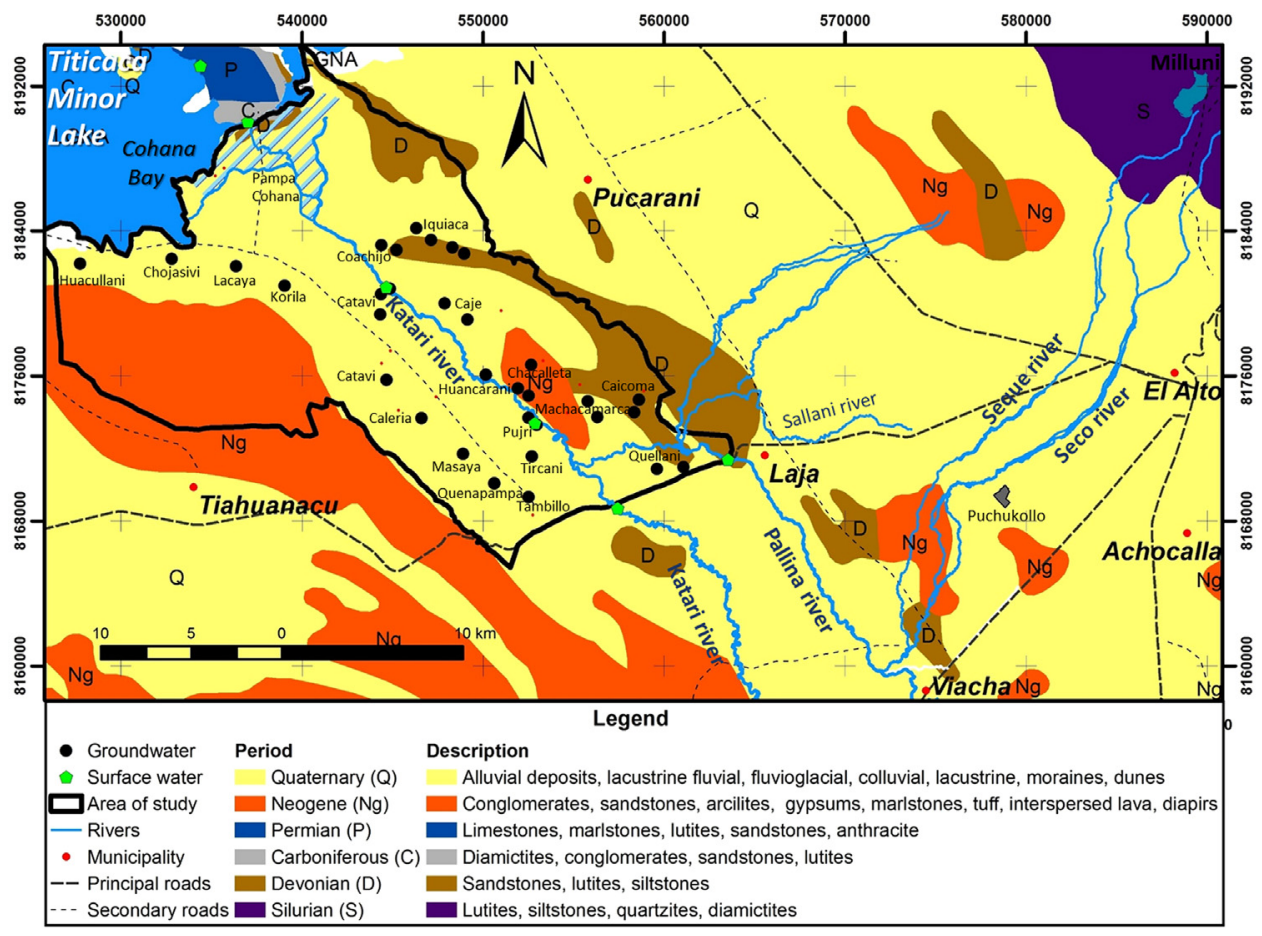

Fig. 2. Geological map of study area and the location of sampling sites.

(IIS, 2013). In this rural region, the drinking water is extracted from excavated wells ( $\sim 10 \mathrm{~m}$ depth); these wells are also used for irrigation and animal consumption and in a few locations there are deep wells with pumps installed.

\subsection{Geology}

Geologically the study area is formed by sandstones, lutites and siltstones belonging to the Devonian period, and conglomerates, sandstones, arcilites, marlstones, with volcanic rocks, as tuff, interspersed lava and diapirs of the Neogene period. Overlapping them there alluvial, fluvial lacustrine, fluvioglacial, colluvial, lacustrine, moraine and dune deposits from Quaternary period are identified (IIS, 2013) (Fig. 2).

The scattered hills that are present in the fluviolacustrine plains (Fig. 2) correspond to outcrops of Devonian sandstones and siltstones (MMAyA, 2010). Lake sediments overlap and are interspersed with fluvial sediments forming confining layers and consequently produce artesian conditions (IIS, 2013). Lake sediments are found under the terraces of the ancient Ballivián Lake (Coudrian-Ribstein et al., 1995a, 1995b).

\section{Material and methods}

\subsection{Sampling}

Sampling was carried out during summer months (rainy season) between December 2014 (shallow GW) and March 2015 (SW). Totally 37 samples were collected, $31 \mathrm{GW}$ and 6 SW (along the Pallina River, Katari River and Titicaca Minor Lake near to Cohana Bay). In the field, the measured parameters were $\mathrm{pH}$, temperature $(\mathrm{T})$, electrical conductivity (EC), redox potential (Eh), total dissolved solids (TDS) with a multiparameter meter HANNA - HI 9828. The Eh values were corrected with respect to hydrogen electrode (Appelo and Postma, 2005). The portable instrument was calibrated daily; all equipment in contact with water was rinsed three times with deionized water. Alkalinity was determined on-site by titration with $0.1 \mathrm{~N} \mathrm{H}_{2} \mathrm{SO}_{4}$ until the color change of a mixed acid-base indicator takes place approximately a $\mathrm{pH}$ of 4 .
The GW samples were taken with a pump, depending on the type of well. The sampling bottles were rinsed three times with well water before samples were taken. In each sampling point the geographical coordinates were taken with a handheld GARMIN GPS12 $2^{\mathrm{Tm}}$. In the wells, the depth to water table was measured with a water level meter (Solinst 101). Other well characteristics such as the depth, construction type, and age of a well were obtained from well owners. The samples were filtered using Sartorius $0.45 \mu \mathrm{m}$ filters and the water samples were collected in three replicates from each site, three bottles of $80 \mathrm{~mL}$ for anions, cations (metals), and As speciation.

The SW samples were taken in the middle of river channel where possible, using a plastic bucket following the same procedure as for groundwater sampling. Water samples were collected for the analysis of major cations, TEs, anions and As speciation, following standard protocol for water sampling (Bhattacharya et al., 2002). In the field, As speciation was performed with Disposable Cartridges (MetalSoft Center, USA), following the methodology described by Meng et al. (2001).

\subsection{Water analysis}

Major anions were analyzed by Dionex Ion Chromatograph (model ICS 1100) at the Environmental Chemistry Laboratory at Universidad Mayor de San Andres (UMSA) in La Paz Bolivia. Major cations were analyzed using Flame Atomic Absorption Spectrometer (FAAS) (Perkin Elmer AAnalyst 200). As (total and III) and other elements were determined by Graphite Furnace Atomic Absorption Spectrometry (GFAAS) at the Hydrochemistry Laboratory of the Universidad Mayor de San Andres (UMSA) in La Paz Bolivia. The As speciation of samples gave the As (III) concentration and subtraction from the sample of As (total) gave the As (V) concentration.

The precision and accuracy of analysis were tested by the internal quality control of the laboratory. The quality assurance of major ion analyses was ensured through the estimation of charge balance error (CBE), most samples were in an acceptable CBE of $\pm 10 \%$ (Table 2). Field blanks and reagent blanks were prepared and analyzed. Certified reference material (NIST SRM 1640a - Trace Elements in Natural Water) was used to check the accuracy. Replicate analyses were carried 
out to check the precision of the results, accuracy and precision indicated variations within the range of $\pm 10 \%$.

\subsection{Data analysis}

Values of variables that were below detection limit, (bdl) or " < DL", were changed to the values divided by two, with the following expression "DL/2" for their treatment in all calculations, according to methodology suggested by Farnham et al. (2002).

The Aquachem software (4.0.264 Waterloo Hydrogeologic Inc, 2003) was used to evaluate the analyses results for water samples; with this software the Piper, Box and Whisker plots where created and the type of water was determined. The hydrochemical facies nomenclature was used according to the methodology suggested by Giménez-Forcada (2010).

Using the Geographic Information Systems (GIS), selected parameters were directly spatialized for SW and the Inverse Distance Weighting (IDW) interpolation was used for GW, with the Geometrical Interval Classification (GIC) method (class ranges based on intervals that have a geometric sequence based on a multiplier), this method was used to visualize continuous data and produces a visually appealing and cartographically complete result (Esri, 2008); these procedures were done in the ArcGIS 10.2.2 software.

The hierarchical cluster analysis (HCA) and principal component analysis (PCA) were used, to classify water samples into different groups based on their hydrochemical characteristics. Using HCA and PCA it is possible to identify the temporal and spatial variation of hydrochemistry. The statistics software InfoStat (Balzarini et al., 2008) was applied to the data. The Shapiro - Wilk (modified) test (Balzarini et al., 2008) was applied to the data to determine normality of distribution.

The HCA consists of grouping the variables based on their similarity (or dissimilarity), each cluster may represent a specific process in the system. The classification scheme used was the Euclidean Distance (continuous variables) for similarity measures and the Method of Ward (minimum variance) for linkage (Guler et al., 2002).

The PCA is a powerful technique for pattern recognition that attempts to explain the variance of a large set of inter-correlated variables and to transform them into a smaller set of independent (uncorrelated) variables (principal components). The Kaiser criterion (Kaiser, 1960) was applied, i.e., only the factors with eigenvalues, greater than or equal to 1 were accepted as possible source of variance in the data.

Saturation indices (SI) and distribution of species in water samples were calculated using the geochemical PHREEQC software (Parkhurst and Appelo, 1999) and the MINTEQ database (minteq.dat).

\section{Results}

The samples were collected from shallow wells $(0.7-9.7 \mathrm{~m}$; mean, $3.8 \mathrm{~m}$ ), with exception of MCHP2 (46 m) and HUAP1 (unknown depth). The groundwater depth (phreatic level) varied from $0.2 \mathrm{~m}$ to $6.3 \mathrm{~m}$ ( $2.6 \mathrm{~m}$, mean), without taken account MCHP2 (14.6 m) and HUAP1 (unknown) (Fig. 3b), the phreatic level gradually increases towards the east and southeast (Fig. 3a, b).

The $\mathrm{pH}$ is slightly alkaline (7.2-8.3) in $97 \%$ of GW samples (7.8, mean) with exception of CCJP1 (9.0), and the same characteristic (6.7-8.5) has in $100 \%$ of SW samples (7.5, mean). The GW samples situated in the plain close to river's course ( $16 \%$ of wells) tend to have a higher $\mathrm{pH}(8.0-9.0)$ than those situated in the elevated regions $(38 \%$ of wells) (7.2-7.7) (Fig. 4a). The sample taken in the Titicaca Minor Lake near to Cascachi village (COL1) has a pH slightly more alkaline (8.5) than that of the others SW samples (Fig. 4a).

The corrected Eh values indicate a range $167.9-235.4 \mathrm{mV}$ (220.1 mV, mean) for $\mathrm{GW}$ and a range $240.9-245.7 \mathrm{mV}(243.6 \mathrm{mV}$, mean) for SW, suggesting a moderately oxidizing environment (Fig. 4b).
The EC is moderate to very high and varies considerably within the study area with a range from 253 to $4674 \mu \mathrm{S} / \mathrm{cm}$ for GW. The SW have moderate to slightly elevated EC values, ranging from 656 to $1125 \mu \mathrm{S}$ / $\mathrm{cm}$ (Table 1), the values are slightly elevated from confluence of the two Pallina and Katari (KAR2) rivers to Cohana Bay (COR1) (Fig. 5a).

Almost all shallow GW samples shows that $\mathrm{Ca}^{2+}(68 \%)$ and $\mathrm{HCO}_{3}{ }^{-}$ $(61 \%)$ are the dominant ions according to the mean values of the measurements $(\mathrm{n}=31)$ shown in the box plot (Fig. $6 \mathrm{~b})$. The water types (hydrochemical facies) are very variable $(n=31)$ (Table 2$)$; just $45 \%$ of the samples are $\mathrm{Ca}-\mathrm{HCO}_{3}$ water type, $19 \%$ of the samples are Ca$\mathrm{Cl}$ and $16 \% \mathrm{Na}-\mathrm{HCO}_{3}$ type (Fig. 7b). The composition of the remaining samples cannot be grouped into a single water type.

Calcium is the predominant major cation $(68 \%)$ in most groundwater samples with a range of $25.1-368.7 \mathrm{mg} / \mathrm{L}(105.4 \mathrm{mg} / \mathrm{L}$, mean) (Fig. 6b). Sodium (32\%) has a range of $7.5-782.5 \mathrm{mg} / \mathrm{L}(126.2 \mathrm{mg} / \mathrm{L}$, mean). The concentrations of the other cations $\left(\mathrm{K}^{+}\right.$and $\left.\mathrm{Mg}^{2+}\right)$ are low compared to $\mathrm{Ca}^{2+}$ and $\mathrm{Na}^{+}$.

The predominant anion in $\mathrm{GW}$ samples is $\mathrm{HCO}_{3}{ }^{-}(61 \%)$ with a range from 101.5 to $378.2 \mathrm{mg} / \mathrm{L}$ (224.6 mg/L, mean) (Figs. 6b, 7b). The concentrations are highest (306.9-378.2 mg/L) in $23 \%$ of the sampling points, which are located close to the Katari River in the flat plain (Pujri, Catavi, Coachijo, Machacamarca) and close to the Pallina River (Quellani).

The $\mathrm{Cl}^{-}(23 \%)$ concentration varies considerably in the area of study ranging between 4.3 and $794 \mathrm{mg} / \mathrm{L}(153.9 \mathrm{mg} / \mathrm{L}$, mean) (Fig. 8a), the values correlate well with EC values $(r=0.94)$ and five samples $(16 \%)$ exceed the NB-512 guideline values $(250 \mathrm{mg} / \mathrm{L})$. The $\mathrm{SO}_{4}{ }^{2-}(16 \%)$ concentrations have a mean of $235.6 \mathrm{mg} / \mathrm{L}$ (Fig. 8b), this anion correlates very well with EC $(r=0.89)$ and very well with $\mathrm{Na}^{+}(r=0.97)$; four samples (13\%) exceed the Bolivian regulation (NB - 512) guideline (400 mg/L).

The $26 \%$ of the wells (8) reaching over $45 \mathrm{mg} / \mathrm{L}$ for $\mathrm{NO}_{3}{ }^{-}$values considering the NB-512 guideline ( $23 \%$ according the WHO guideline values: $50 \mathrm{mg} / \mathrm{L}$ ); the range is $0.2-221.4 \mathrm{mg} / \mathrm{L},(30.3 \mathrm{mg} / \mathrm{L}$ mean) (Fig. 5b). Lacaya (LACP1), Chacalleta (CHCP1) and Caicoma (CYCP1) wells have the highest concentrations while the others wells in general have low values (Table 1 ).

In SW, $67 \%$ are of a $\mathrm{Na}$, Ca-Mix $\mathrm{HCO}_{3}$ (Fig. 7a) water type $(\mathrm{n}=6)$ (Table 2), $\mathrm{Na}^{+}(67 \%)$ and $\mathrm{HCO}_{3}{ }^{-}(83 \%)$ are the predominant ions (Figs. 6a, 7a), the concentrations of major ions are lower than in GW (Fig. 6a, b), and the variability of water type classifications are not higher as GW samples (Fig. 7a, b).

Total dissolved As concentration ranges from 0.75 to $89.7 \mu \mathrm{g} / \mathrm{L}$ with mean of $16.1 \mu \mathrm{g} / \mathrm{L}(\mathrm{n}=31)$ for shallow GW. More than $48 \%$ of samples (15 out of the 31 sampled wells) exceeded the WHO and NB-512 guideline $(10 \mu \mathrm{g} / \mathrm{L})$, for drinking water. In the SW samples only one sample (PAR1, $11.7 \mu \mathrm{g} / \mathrm{L}$ ) exceeded both guideline (17\% of the samples; $\mathrm{n}=6)$.

The samples in Pujri (PUJP1, $44.1 \mu \mathrm{g} / \mathrm{L}$ ), Coachijo (CUAP1, $33.2 \mu \mathrm{g} /$ L), Korila (KOP1, 64.4 $\mu \mathrm{g} / \mathrm{L}$ ) and Iquiaca (IQUP1, $89.7 \mu \mathrm{g} / \mathrm{L}$ ) have highest concentrations of As. Huacullani (HUAP1), Chojasivi (CHJP1) and Lacaya (LACP1) have more than double of As concentration permitted for drinking water in accordance with the WHO and NB-512 guidelines.

There is a slight trend of increasing concentrations of As from Southeast to Northwest, the As concentration apparently increases in the wells close to the bank of the Titicaca Minor Lake (Fig. 9).

The GW samples plotted in the Eh-pH diagram suggest that $\mathrm{H}_{2} \mathrm{AsO}_{4}{ }^{-}$ and $\mathrm{HAsO}_{4}{ }^{2-}$ are the dominant As species (Fig. 10). The redox status in aquifers is related to the depth of the GW, which most of them are shallow GW and show oxidizing conditions (Fig. 4b).

The calculation by the hydrochemical code PHREEQC indicate that the predominant species is As $(\mathrm{V})$, with different degree of protonation: $\mathrm{HAsO}_{4}{ }^{2-}(56 \%)$ and $\mathrm{H}_{2} \mathrm{AsO}_{4}{ }^{-}(7 \%)$, besides $\mathrm{CaHAsO}_{4}(19 \%), \mathrm{MgHAsO}_{4}$ (11\%) and $\mathrm{MgAsO}_{4}^{-}(8 \%)$, while As (III) is present as $\mathrm{H}_{3} \mathrm{AsO}_{3}(96 \%)$. There is not a trend linking the high As level to a specific water type. 

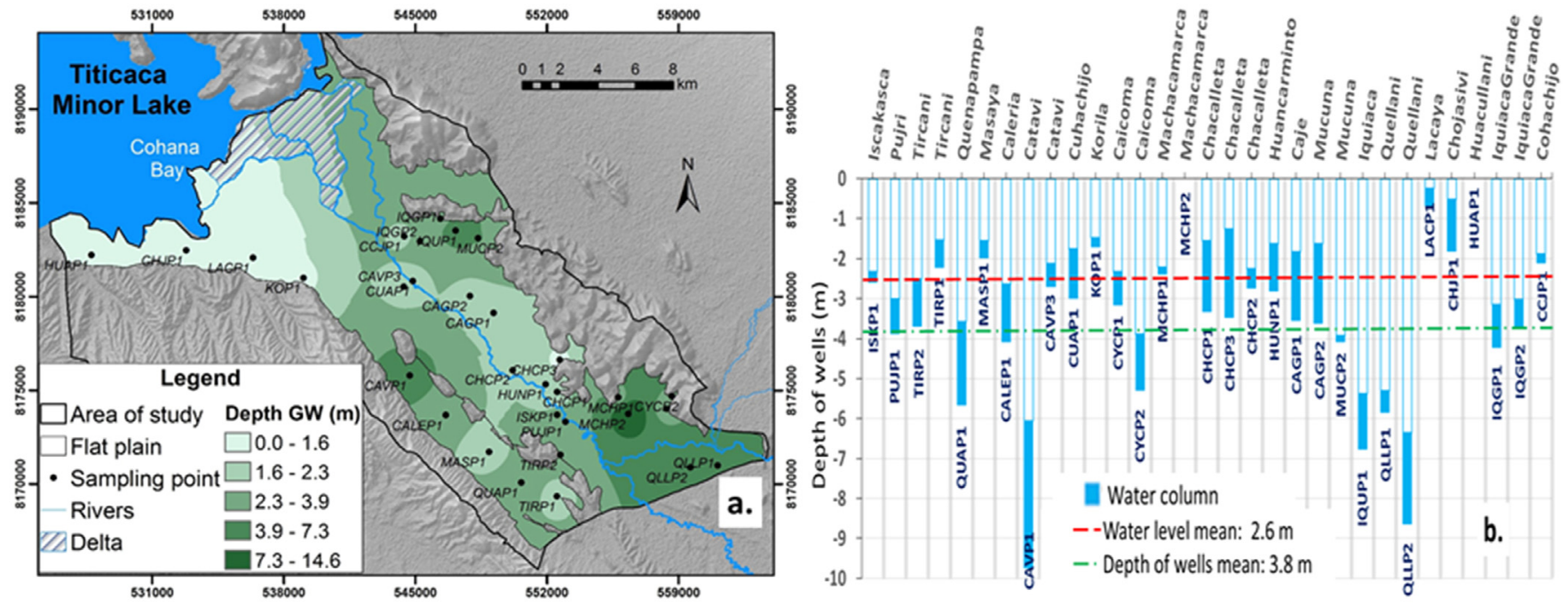

Fig. 3. Spatial variations in the depth to groundwater (GW) with GIC method (a) and water column of the wells (b).

In general, the dissolved TEs ( $\mathrm{Cu}, \mathrm{Fe}, \mathrm{Mn}, \mathrm{Pb}, \mathrm{Cd}$ and $\mathrm{Zn})$ concentrations are very low (Fig. 11b), with some exceptions such as Fe (TIRP2, $144 \mu \mathrm{g} / \mathrm{L} ; \mathrm{KOP} 1,156 \mu \mathrm{g} / \mathrm{L}$ ), Mn (IQUP1, $137 \mu \mathrm{g} / \mathrm{L}$; IQGP2, $95 \mu \mathrm{g} / \mathrm{L})$ and $\mathrm{Zn}(\mathrm{MCHP} 2,142 \mu \mathrm{g} / \mathrm{L})$. All GW samples have levels below the WHO guidelines values. In SW samples, only one sample exceeded the NB - 512 guidelines (Table 1) with a concentration of Fe $419 \mu \mathrm{g} / \mathrm{L}$ (PAR1). The concentrations in SW of dissolved $\mathrm{Cu}, \mathrm{Fe}, \mathrm{Mn}, \mathrm{Pb}, \mathrm{Cd}$ and Zn are very low too (Fig. 11a), except the sample KAR3 (Mn, $88 \mu \mathrm{g} / \mathrm{L}$ and $\mathrm{Zn}, 279 \mu \mathrm{g} / \mathrm{L}$ ).

In SW samples, there is a decrease of concentrations for three TEs (Fe, Mn, Zn) after of the confluence the Pallina and Katari rivers (KAR2: Fe, $57 \mu \mathrm{g} / \mathrm{L} ; \mathrm{Mn}, 10 \mu \mathrm{g} / \mathrm{L} ; \mathrm{Zn}, 2.5 \mu \mathrm{g} / \mathrm{L}$ ), due to the dilution effect from Katari River (KAR1: Fe, $15 \mu \mathrm{g} / \mathrm{L} ; \mathrm{Mn}, 45 \mu \mathrm{g} / \mathrm{L} ; \mathrm{Zn}, 54 \mu \mathrm{g} / \mathrm{L}$ ) on the Pallina River (PAR1: Fe, $419 \mu \mathrm{g} / \mathrm{L} ; \mathrm{Mn}, 64 \mu \mathrm{g} / \mathrm{L} ; \mathrm{Zn}, 79 \mu \mathrm{g} / \mathrm{L}$ ).

In general, the GW samples are not normally distributed due to the presence of outliers in the dataset. In the case of the SW samples almost $70 \%$ of samples are normally distributed.

The HCA results are reported in the form of dendrograms (Fig. 12), considering the distances between parameters and their position on the dendrograms, clusters of the variables were defined for the data.

According to the criterion of cut at $50 \%$, the maximum distance of 15.3 was applied by Balzarini et al. (2008). The distinction between clusters in the analysis results in 6 groups defined according to the distance (Fig. 12).

The six groups are visible from the cluster analysis of data, the first group (blue color): PUJP1, ISKP1, and CAVP3 with elevated salinity (EC, TDS), this group has high concentrations of $\mathrm{SO}_{4}{ }^{2-}, \mathrm{Cl}^{-}, \mathrm{HCO}_{3}{ }^{-}, \mathrm{Na}^{+}$, $\mathrm{Ca}^{2+}$, and $\mathrm{Mg}^{2+}$. The second group (gray color) has 16 samples and its characteristics are variable because there is not clear tendency in relation to water parameters. The third group (green color): PAR1 and KAR3 are SW samples. This group has important presence of TEs, Fe is predominant in PAR1 (Pallina River) besides of $\mathrm{Mn}, \mathrm{Zn}$, and As. In KAR3 (downstream of the Katari River) $\mathrm{Zn}$ is predominant followed by $\mathrm{Mn}, \mathrm{Fe}$ and $\mathrm{Cd}$. The fourth group (yellow color): KOP1 and IQUP1 have arsenic as most important element, the $\mathrm{HCO}_{3}{ }^{-}$, Fe and $\mathrm{Mn}$ also are presents with concentrations important in relation with the other groups. The fifth group (pink color) has eleven GW samples, the $\mathrm{HCO}_{3}$, $\mathrm{Ca}^{2+}$ and $\mathrm{Mg}^{2+}$ are in decreasing order of importance. Finally, the sixth group (red color) corresponds to three GW samples (CHCP2, CAGP2, CAGP1) with elevated concentrations of $\mathrm{NO}_{3}{ }^{-}, \mathrm{HCO}_{3}{ }^{-}, \mathrm{Cl}^{-}, \mathrm{Ca}^{2+}, \mathrm{K}^{+}$and $\mathrm{Mg}^{2+}$.

The HCA was also applied to the mean values of each parameter and the result is show in Fig. 13. In the dendrogram, the three groups into which the measured parameters are divided are observed. In the first, the parameters directly related to salinity (TDS and EC), in the second the major ions $\left(\mathrm{SO}_{4}{ }^{2-}, \mathrm{HCO}_{3}{ }^{2-}, \mathrm{Cl}^{-}, \mathrm{Ca}^{2+}\right.$ and $\left.\mathrm{Na}^{+}\right)$and finally, the TEs
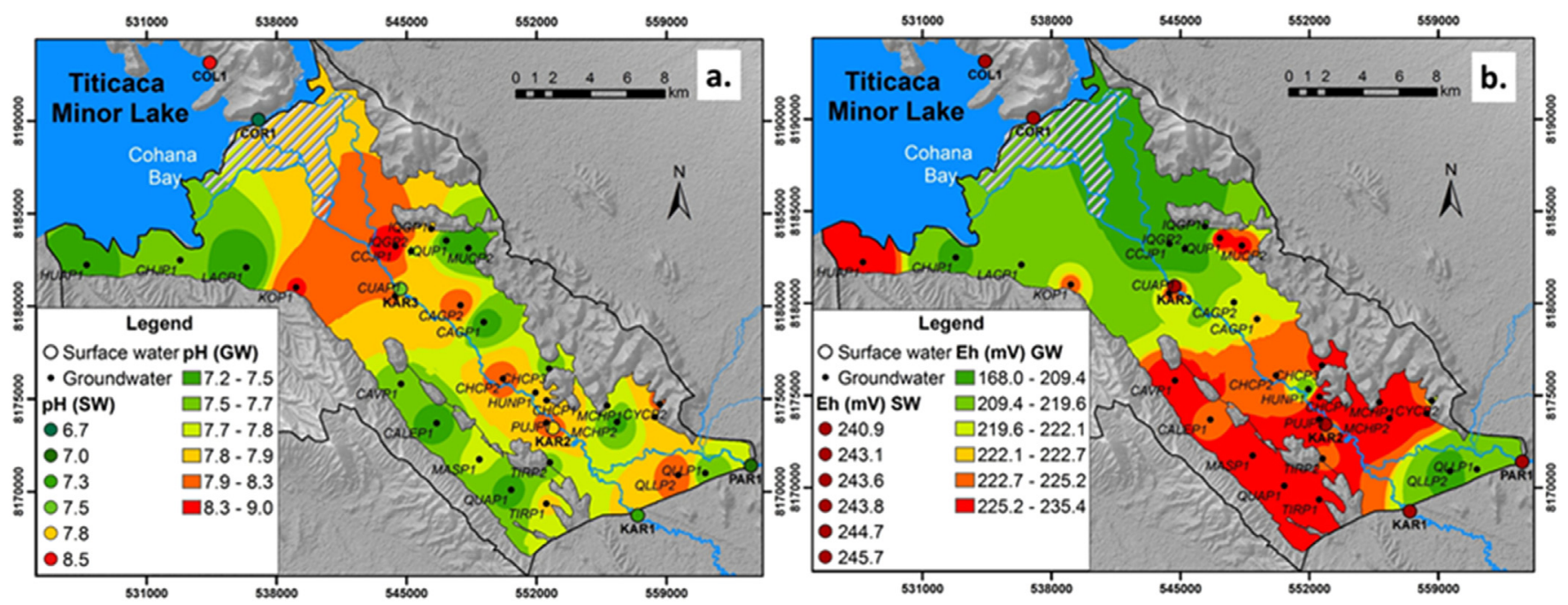

Fig. 4. Spatial distribution of $\mathrm{pH}$ (a) and Eh (b) in GW and SW in shallow aquifer in the study area with (GIC) method (Esri, 2008). 
Table 1

Summary statistics of parameters and concentrations in GW and SW and $\mathrm{WHO}^{\mathrm{a}}$ and NB-512 ${ }^{\mathrm{b}}$ guideline values.

\begin{tabular}{|c|c|c|c|c|c|c|c|c|c|}
\hline \multicolumn{4}{|l|}{ GW $(n=31)$} & \multirow[b]{2}{*}{ WHO limit } & \multirow[b]{2}{*}{ NB-512 limit } & \multicolumn{4}{|l|}{$S W(n=6)$} \\
\hline Parameter & Min & Max & Mean & & & Parameter & Min & Max & Mean \\
\hline $\mathrm{pH}$ & 7.2 & 9.0 & 7.8 & - & - & $\mathrm{pH}$ & 6.7 & 8.6 & 7.5 \\
\hline $\mathrm{EC}(\mu \mathrm{S} / \mathrm{cm})$ & 253 & 4674 & 1305.3 & - & 1500 & $\mathrm{EC}(\mu \mathrm{S} / \mathrm{cm})$ & 656 & 1125 & 862.7 \\
\hline Eh $(\mathrm{mV})$ & 167.9 & 235.4 & 220.1 & - & - & Eh $(\mathrm{mV})$ & 240.9 & 245.7 & 243.6 \\
\hline $\mathrm{T}\left({ }^{\circ} \mathrm{C}\right)$ & 11.4 & 21.4 & 14.2 & - & - & $\mathrm{T}\left({ }^{\circ} \mathrm{C}\right)$ & 14.0 & 19.4 & 15.9 \\
\hline TDS (mg/L) & 126 & 2949 & 682 & - & - & TDS (mg/L) & 328.0 & 606.0 & 435.5 \\
\hline $\mathrm{HCO}_{3}^{-}(\mathrm{mg} / \mathrm{L})$ & 101.5 & 378.2 & 224.6 & - & - & $\mathrm{HCO}_{3}^{-}(\mathrm{mg} / \mathrm{L})$ & 103.0 & 181.5 & 137.8 \\
\hline $\mathrm{Cl}^{-}(\mathrm{mg} / \mathrm{L})$ & 4.3 & 794 & 154.0 & - & 250 & $\mathrm{Cl}^{-}(\mathrm{mg} / \mathrm{L})$ & 51.0 & 74.0 & 59.5 \\
\hline $\mathrm{NO}_{3}^{-}(\mathrm{mg} / \mathrm{L})$ & 0.3 & 221.4 & 30.3 & 50 & 45 & $\mathrm{NO}_{3}^{-}(\mathrm{mg} / \mathrm{L})$ & 2.2 & 9.9 & 7.0 \\
\hline $\mathrm{SO}_{4}{ }^{2-}(\mathrm{mg} / \mathrm{L})$ & 11 & 1471 & 235.6 & - & 400 & $\mathrm{SO}_{4}{ }^{2-}(\mathrm{mg} / \mathrm{L})$ & 51.5 & 135.2 & 75.2 \\
\hline- & - & - & - & - & - & $\mathrm{PO}_{4}{ }^{3-}(\mathrm{mg} / \mathrm{L})$ & 0.03 & 1.37 & 0.56 \\
\hline $\mathrm{Ca}^{2+}(\mathrm{mg} / \mathrm{L})$ & 25.1 & 368.8 & 105,4 & - & 200 & $\mathrm{Ca}^{2+}(\mathrm{mg} / \mathrm{L})$ & 21.4 & 44.2 & 34.4 \\
\hline $\mathrm{Mg}^{2+}(\mathrm{mg} / \mathrm{L})$ & 2.6 & 68 & 22.8 & - & 150 & $\mathrm{Mg}^{2+}(\mathrm{mg} / \mathrm{L})$ & 8.4 & 11.7 & 9.9 \\
\hline $\mathrm{K}^{+}(\mathrm{mg} / \mathrm{L})$ & 2.4 & 65.5 & 14.4 & - & - & $\mathrm{K}^{+}(\mathrm{mg} / \mathrm{L})$ & 5.4 & 10.0 & 8.0 \\
\hline $\mathrm{Na}^{+}(\mathrm{mg} / \mathrm{L})$ & 7.6 & 782.5 & 126.2 & - & 200 & $\mathrm{Na}^{+}(\mathrm{mg} / \mathrm{L})$ & 46.8 & 115.0 & 64.1 \\
\hline $\mathrm{Cu}(\mu \mathrm{g} / \mathrm{L})$ & 0.01 & 6.9 & 0.9 & 2000 & 1000 & $\mathrm{Cu}(\mu \mathrm{g} / \mathrm{L})$ & 0.3 & 4.8 & 1.8 \\
\hline $\mathrm{Fe}(\mu \mathrm{g} / \mathrm{L})$ & 15 & 156 & 24.4 & - & 300 & $\mathrm{Fe}(\mu \mathrm{g} / \mathrm{L})$ & 15.0 & 419.0 & 97.3 \\
\hline $\mathrm{Mn}(\mu \mathrm{g} / \mathrm{L})$ & 10 & 137 & 18.5 & 400 & 100 & $\operatorname{Mn}(\mu \mathrm{g} / \mathrm{L})$ & 10.0 & 88.0 & 40.2 \\
\hline $\mathrm{Pb}(\mu \mathrm{g} / \mathrm{L})$ & 0.75 & 4.8 & 1.0 & 10 & 10 & $\mathrm{~Pb}(\mu \mathrm{g} / \mathrm{L})$ & 0.75 & 0.75 & 0.75 \\
\hline $\mathrm{Cd}(\mu \mathrm{g} / \mathrm{L})$ & 0.10 & 0.41 & 0.14 & 3 & 5 & $\mathrm{Cd}(\mu \mathrm{g} / \mathrm{L})$ & 0.10 & 0.66 & 0.22 \\
\hline $\mathrm{Zn}(\mu \mathrm{g} / \mathrm{L})$ & 2.5 & 142 & 17.7 & - & 5000 & $\mathrm{Zn}(\mu \mathrm{g} / \mathrm{L})$ & 2.5 & 279.0 & 69.9 \\
\hline As (total) $(\mu \mathrm{g} / \mathrm{L})$ & 0.75 & 89.66 & 16.09 & 10 & 10 & As (total) $(\mu \mathrm{g} / \mathrm{L})$ & 2.10 & 11.66 & 5.99 \\
\hline As (III) $(\mu \mathrm{g} / \mathrm{L})$ & 0.39 & 11.19 & 2.47 & - & - & As (III) $(\mu \mathrm{g} / \mathrm{L})$ & 1.51 & 6.42 & 2.88 \\
\hline
\end{tabular}

a WHO, World Health Organization's guidelines for drinking water quality.

b NB-512, Bolivian regulation for drinking water.
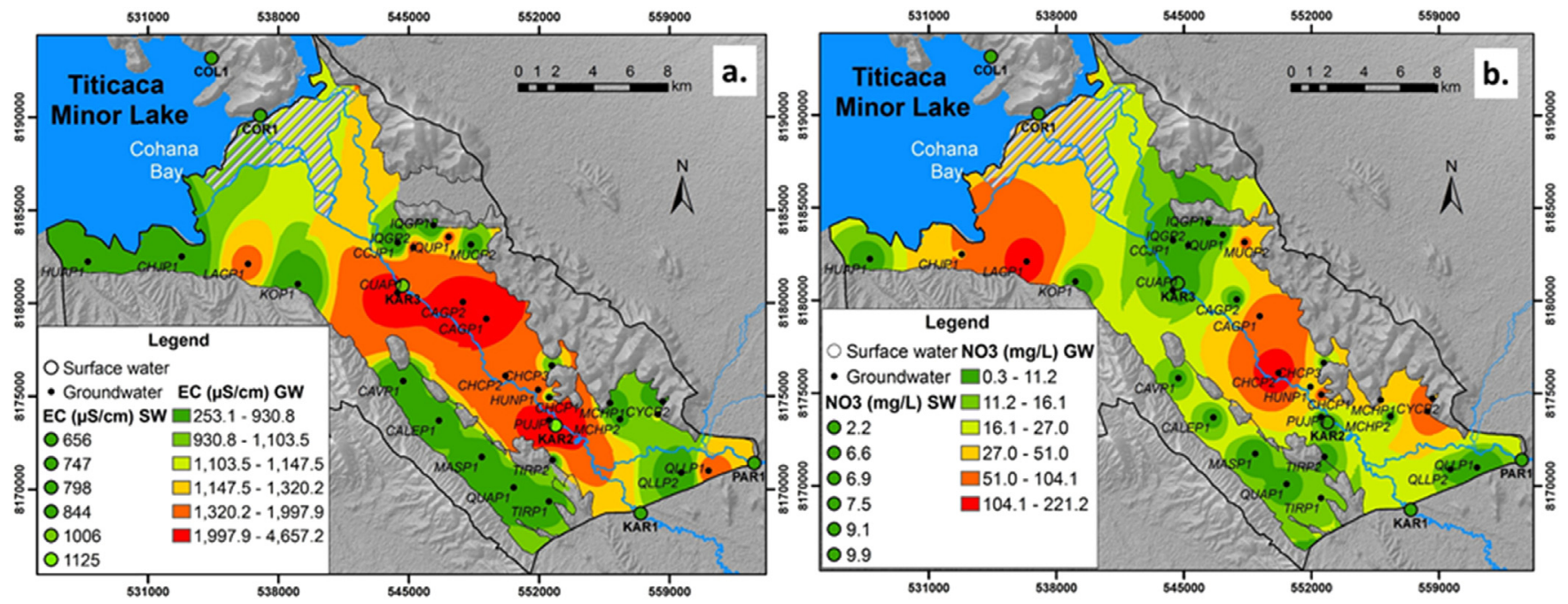

Fig. 5. Spatial distribution of: $\mathrm{EC}$ (a), $\mathrm{NO}_{3}{ }^{-}$(b) in $\mathrm{GW}$ and $\mathrm{SW}$, with (GIC) method (Esri, 2008).

( $\mathrm{Mn}, \mathrm{As}, \mathrm{Fe}, \mathrm{Pb}, \mathrm{Zn}, \mathrm{Cu}$ and $\mathrm{Cd}$ ) in the third group.

Using the Kaiser criterion only the first three factors that explained $59 \%$ of the total variance were used in the PCA (Table 3). The bold values in Table 3 indicate component loadings higher than 0.5 and these values are considered important contributors to the total variance.

The first component (PC1) is responsible for 33\% of the total variance. This component has strong positive loadings $(>|0.5|)$ for EC, TDS, $\mathrm{Cl}^{-}, \mathrm{SO}_{4}{ }^{2-}$ and $\mathrm{Na}^{+}$, the $\mathrm{Mg}^{2+}, \mathrm{Pb}, \mathrm{Ca}^{2+}$ and $\mathrm{Cd}$ have moderate positive loadings. The PC2 which explains $14 \%$ of total variance has positive loadings for As and Mn. Finally, $12 \%$ of the total variance can be explained by PC3 represented by TEs such as $\mathrm{Zn}, \mathrm{Cd}$ and $\mathrm{Cu}$ (Table 3).

The scatter plot (Fig. 14) for the first two components (PC1 vs PC 2) is the first factorial plan ( $47 \%$ of the total variance). This plot shows how the variables group together along the new axes which now contain the most important information about the variation in the dataset
(Balzarini et al., 2008).

The Fig. 14 shows $47 \%$ of the total variance in data set. In this figure, four groups are clearly visible and there are many similarities with the HCA. The first group: PUJP1, ISKP1, CAVP3 and CAGP2 has elevated salinity and is related to EC, TDS, and also $\mathrm{SO}_{4}{ }^{2-}$ and in minor magnitude to $\mathrm{Cl}^{-}, \mathrm{HCO}_{3}^{-}, \mathrm{Na}^{+}, \mathrm{Ca}^{2+}$, and $\mathrm{Mg}^{2+}$. The second group (G2): PAR1, KOP1, TIRP2 and KAR3 is related to the third group (G3): CUAP1 and IQUP1. These groups have important presence of TEs: As, $\mathrm{Fe}$ and $\mathrm{Mn}$ besides $\mathrm{Zn}$ and $\mathrm{Cu}$, the ion $\mathrm{HCO}_{3}{ }^{-}$is present too. Both groups have redox sensitive elements and for that reason Eh is strongly related to G2 and G3. Finally, the fourth group (G4): CYCP1, LACP1 and CHCP2 is strongly related to $\mathrm{NO}_{3}{ }^{-}$and $\mathrm{K}^{+}$.

The results of hydrochemical modelling using PHREEQC indicate that the GW is supersaturated with respect to the Fe-oxide/hydroxides. In contrast, the saturation indices for carbonate minerals are generally negative (Table 4). 

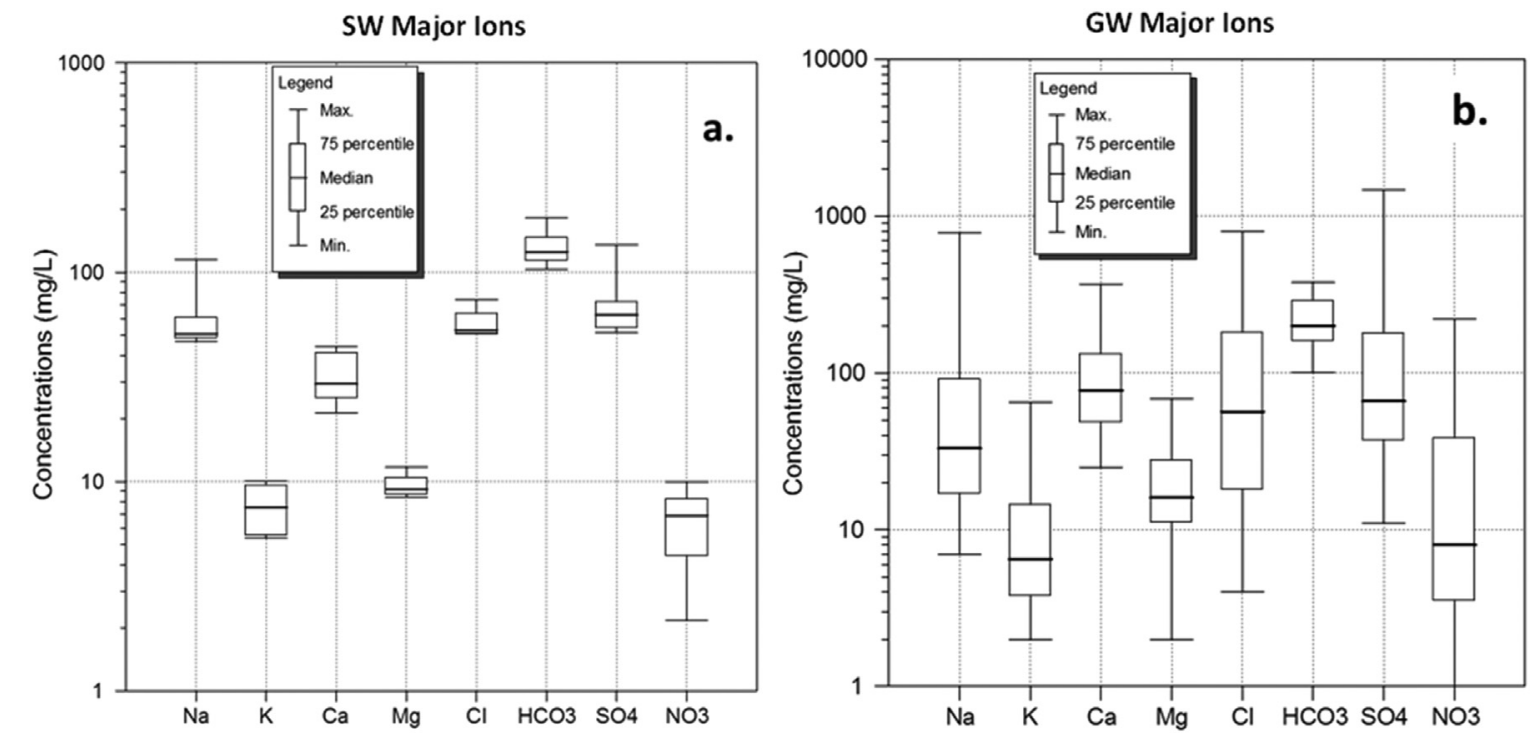

Fig. 6. Box and Whisker plot for the distribution of major ions in SW samples (a) and GW samples (b).

Table 2

Water type in groundwater (GW) and surface water (SW) samples.

\begin{tabular}{|c|c|c|c|c|c|c|c|}
\hline Sample ID & Location & Water type & $\mathrm{CBE}^{\mathrm{a}}(\%)$ & Sample ID & Location & Water type & $\operatorname{CBE}^{\mathrm{a}}(\%)$ \\
\hline$G W$ & & & & $G W$ & & & \\
\hline ISKP1 & Iscakasca & $\mathrm{Na}-\mathrm{SO}_{4}, \mathrm{Cl}$ & -7.9 & CAGP1 & Caje & $\mathrm{Ca}-\mathrm{Cl}$ & 9.9 \\
\hline PUJP1 & Pujri & $\mathrm{Na}-\mathrm{SO}_{4}, \mathrm{Cl}$ & -6.8 & CAGP2 & Mucuna & $\mathrm{Ca}, \mathrm{Na}-\mathrm{SO}_{4}, \mathrm{Cl}$ & 3.8 \\
\hline TIRP2 & Tircani & $\mathrm{Na}, \mathrm{Ca}-\mathrm{SO}_{4}, \mathrm{HCO}_{3}$ & -4.8 & MUCP2 & Mucuna & MixCa-Cl, $\mathrm{HCO}_{3}$ & 2.4 \\
\hline TIRP1 & Tircani & $\mathrm{Ca}-\mathrm{HCO}_{3}, \mathrm{SO}_{4}$ & -2.8 & IQUP1 & Iquiaca & $\mathrm{Na}, \mathrm{Ca}-\mathrm{MixHCO}_{3}$ & 1.2 \\
\hline QUAP1 & Quenapampa & $\mathrm{Ca}-\mathrm{HCO}_{3}, \mathrm{SO}_{4}$ & -7.3 & QLLP1 & Quellani & $\mathrm{Ca}, \mathrm{Na}-\mathrm{Cl}, \mathrm{HCO}_{3}$ & 0.4 \\
\hline MASP1 & Masaya & $\mathrm{Ca}, \mathrm{Mg}-\mathrm{HCO}_{3}, \mathrm{SO}_{4}$ & 6.8 & QLLP2 & Quellani & $\mathrm{MixNa}-\mathrm{HCO}_{3}$ & -0.2 \\
\hline CALEP1 & Caleria & $\mathrm{Ca}, \mathrm{Mg}-\mathrm{HCO}_{3}$ & 5.2 & LACP1 & Lacaya & $\mathrm{Ca}-\mathrm{Cl}, \mathrm{HCO}_{3}$ & 4.0 \\
\hline CAVP1 & Catavi & $\mathrm{Ca}, \mathrm{Na}-\mathrm{HCO}_{3}$ & 4.8 & CHJP1 & Chojasivi & $\mathrm{Ca}, \mathrm{K}-\mathrm{HCO}_{3}, \mathrm{Cl}$ & -3.6 \\
\hline CAVP3 & Catavi & $\mathrm{Na}-\mathrm{SO}_{4}, \mathrm{Cl}$ & -7.3 & HUAP1 & Huacullani & $\mathrm{Ca}-\mathrm{HCO}_{3}$ & -5.7 \\
\hline CUAP1 & Cuhachijo & $\mathrm{Ca}, \mathrm{Na}-\mathrm{HCO}_{3}, \mathrm{Cl}$ & 5.8 & IQGP1 & Iquiaca & $\mathrm{Ca}-\mathrm{HCO}_{3}$ & -5.5 \\
\hline KOP1 & Korila & $\mathrm{MixNa}-\mathrm{HCO}_{3}$ & -6.6 & IQGP2 & Iquiaca & $\mathrm{Na}, \mathrm{Ca}-\mathrm{MixCl}$ & -2.3 \\
\hline CYCP1 & Caicoma & $\mathrm{Ca}-\mathrm{Na}-\mathrm{HCO}_{3}-\mathrm{Cl}$ & 4.6 & CCJP1 & Cohachijo & $\mathrm{MixNa}-\mathrm{HCO}_{3}$ & -0.5 \\
\hline CYCP2 & Caicoma & $\mathrm{Ca}, \mathrm{Mg}-\mathrm{HCO}_{3}, \mathrm{SO}_{4}$ & 5.4 & $s w$ & & & \\
\hline MCHP1 & Machacamarca & $\mathrm{Ca}, \mathrm{Mg}-\mathrm{HCO}_{3}$ & 0.0 & PAR1 & Pallina river (bridge) & $\mathrm{Ca}, \mathrm{Na}-\mathrm{MixHCO}_{3}$ & -11.7 \\
\hline MCHP2 & Machacamarca & MixNa- $\mathrm{HCO}_{3}, \mathrm{SO}_{4}$ & -5.0 & KAR1 & Katari river (bridge) & $\mathrm{Na}, \mathrm{Ca}-\mathrm{MixHCO}_{3}$ & -11.5 \\
\hline CHCP1 & Chacalleta & $\mathrm{Ca}, \mathrm{Na}-\mathrm{HCO}_{3}, \mathrm{Cl}$ & 2.7 & KAR2 & Union Katari-Pallina river & $\mathrm{Ca}, \mathrm{Na}-\mathrm{MixSO}_{4}$ & 2.3 \\
\hline СHCP3 & Chacalleta & $\mathrm{Ca}-\mathrm{HCO}_{3}, \mathrm{Cl}$ & -1.9 & KAR3 & Katari river (Cohachijo) & $\mathrm{Na}, \mathrm{Ca}-\mathrm{MixHCO}_{3}$ & -2.4 \\
\hline СНCР2 & Chacalleta & $\mathrm{Ca}-\mathrm{Cl}, \mathrm{NO}_{3}$ & 3.4 & COR1 & Cohana (village) & $\mathrm{Na}, \mathrm{Ca}-\mathrm{MixHCO}_{3}$ & 19.9 \\
\hline HUNP1 & Huancarminto & Ca,Mg-MixCl & -9.6 & COL1 & Titicaca Lake (Cascachi) & $\mathrm{Na}, \mathrm{Ca}-\mathrm{MixHCO}_{3}$ & -4.6 \\
\hline
\end{tabular}

${ }^{\text {a }}$ Charge balance error, $\mathrm{CBE}=(($ cation - Sanion $) /($ cation + Lanion $)) \times 100$.

\section{Discussion}

The water level of shallow GW decrease in the excavated wells that are closer to the Titicaca Lake (Fig. 3), this trend suggests that human activities close to wells affect their water quality almost directly (i.e. $\mathrm{NO}_{3}{ }^{-}$input), in Lacaya and Chojasivi (LACP1, $0.25 \mathrm{~m}$ and CHJP1, $0.53 \mathrm{~m}) 137.3$ and $50.9 \mathrm{mg} / \mathrm{L}$, respectively; this is consistent with the PCA biplot results. The elevated concentrations of $\mathrm{NO}_{3}{ }^{-}, \mathrm{K}^{+}$and $\mathrm{Mg}^{2+}$ reflect the contribution of organic and artificial fertilizers from agricultural activities (group 6 of HCA). In surface water, the sample PAR1 (group 3 of HCA) by its geographic location is probably most affected by anthropogenic activities due to water originating from activities in cities (El Alto and Viacha). Another explanation for the elevated concentrations of $\mathrm{NO}_{3}{ }^{-}$in both wells could be the interaction of the GW with SW affected by eutrophication (Titicaca Minor Lake) in wet season.

The water quality in study area is result of the interaction of water with sediments, which in the past were deposited in paleo-lakes (Servant-Vildary and Mello e Sousa, 1993). In the flat plain area where
$64 \%$ of the wells are located on alluvial and glaciofluvial deposits, formed in lacustrine environment in the Quaternary period (IIS, 2013) (Fig. 2) (group 1 of HCA) has the EC predominantly linked to $\mathrm{SO}_{4}{ }^{2-}$. Almost all wells located in this area are used as a source of drinking water and they are manually excavated (INE, 2017).

The wells around the plain and close to river have high EC values due to the lacustrine origin of sediments and by evaporative concentration in a semi-arid climate (Ormachea et al., 2013; Ramos et al., 2014). High EC values in groundwater are linked to the presence of saline groundwater (Fig. 5a); the Lower Katari Basin is located in a region where there were paleo-lakes discussed by Minchin (1882), Argollo and Mourguiart (2000), and Fornari et al. (2001). The salt deposit of these paleo-lakes and evaporative enrichment are responsible for high EC values in the region (Ramos Ramos et al., 2012, 2014).

The neutral-alkaline $\mathrm{pH}$ values, $\mathrm{HCO}_{3}{ }^{-}$and $\mathrm{Na}^{+}$ion water type in the GW, can be linked to cation exchange process (Ravenscroft and Mcarthur, 2004; Bundschuh et al., 2004; Bhattacharya et al., 2006) and probably also to silicate hydrolysis. This relation between ions is observed in HCA (variables) results. (Fig. 13) The enrichment of $\mathrm{Na}^{+}$and 

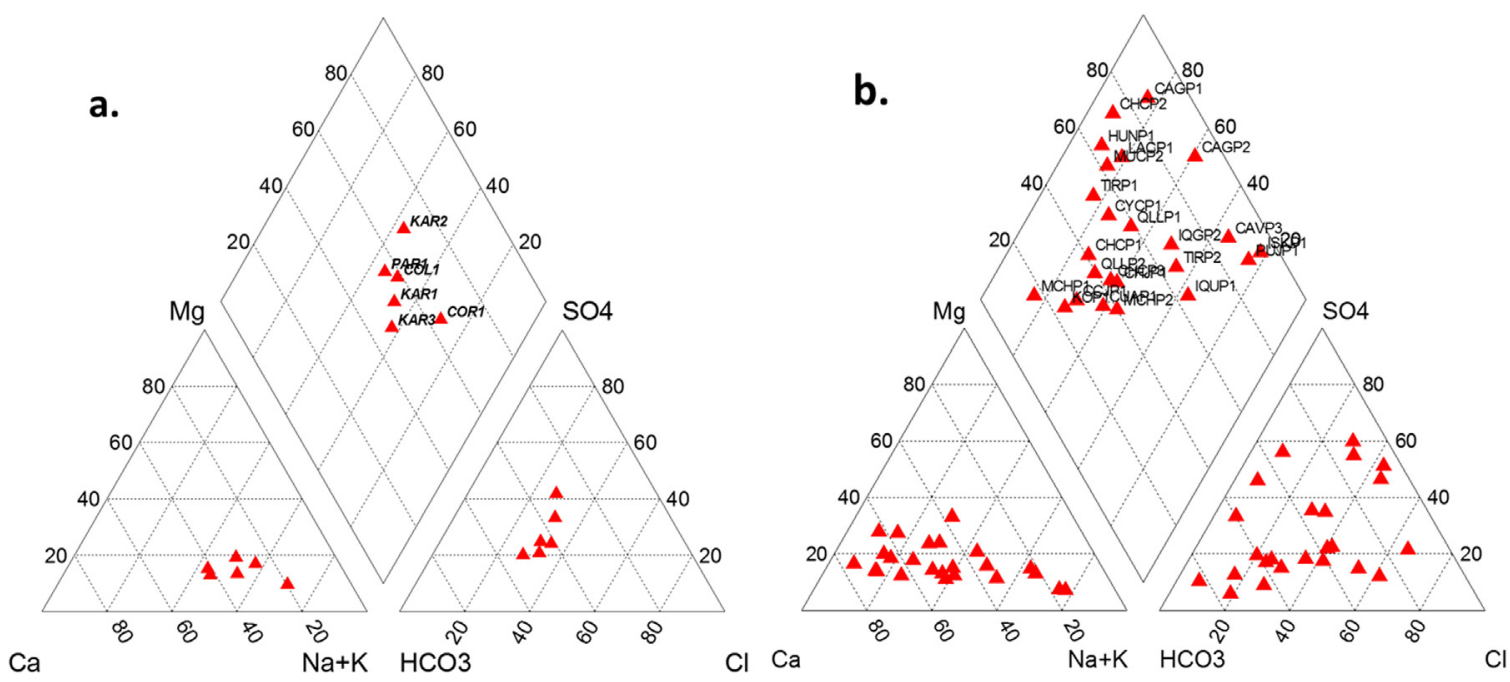

Fig. 7. Piper plot for major ion chemistry of: a) surface water (SW) and b) groundwater (GW) in relation with their water type.

$\mathrm{Cl}^{-}$in groundwater could be linked to halite dissolution in the Quaternary sediments (Ramos Ramos et al., 2014).

The dominant anion in $\mathrm{GW}$ is $\mathrm{HCO}_{3}{ }^{-}$; however, the high salinity (EC) has a major correlation whit $\mathrm{Cl}^{-}(0.94)$ and $\mathrm{SO}_{4}{ }^{2-}(0.84)$. This is consistent with PC1 (first component with strong positive loadings) and with the PCA biplot results and the dissolution of minerals such as gypsum and halite could be responsible for elevated concentrations and salinity. These anions are presents in wells that are in regions near to the Katari River: Pujri, Iskakaspa, Catavi, and Mucuna. These wells coincide precisely with the sampling points close to the Katari River (KAR2 and KAR3) and they have major salinity compared to other points on the river. This suggests a relation between GW and SW, meaning that the GW is recharged by SW.

There is probably dissolution of calcite, dolomite and gypsum in sediments which is linked to the $\mathrm{pH}$ range 7.2-9.0 (Table 1). The dominant presence of $\mathrm{Ca}^{2+}$ is probably contributed from calcareous soils according to HCA (group 5) (Fig. 2). The source of $\mathrm{Ca}^{2+}$ can be partly the dissolution of calcareous rocks (Yidana et al., 2008; Ormachea et al., 2013) and sediments of Quaternary lakes deposited in drier climate between 8000 and 1500 BP (Coudrain-Ribstein et al., 1995a, 1995b), such as calcite, aragonite and dolomite as suggested by the geochemical modelling.

The clustering of variables (HCA) highlight in its three groups: the salinity of the water samples (TDS and EC) $; \mathrm{HCO}_{3}{ }^{-}, \mathrm{Cl}^{-}, \mathrm{SO}_{4}{ }^{2-}, \mathrm{Ca}^{2+}$ and $\mathrm{Na}^{+}$as predominant ions. $\mathrm{Ca}^{2+}$ derived probably from calcareous sediments (Yidana et al., 2008) and $\mathrm{Cl}^{-}$and $\mathrm{Na}^{+}$as dissolution of $\mathrm{Na}-\mathrm{Cl}$ salts. Finally, the TEs ( $\mathrm{Mn}, \mathrm{As}, \mathrm{Fe}, \mathrm{Pb}, \mathrm{Zn}, \mathrm{Cu}$ and $\mathrm{Cd}$ ), together with $\mathrm{NO}_{3}{ }^{-}, \mathrm{K}^{+}$, and $\mathrm{Mg}^{2+}$ can be attributed to anthropogenic influence.

According to the PCA the first clustering (PC1) of variables (EC, TDS, $\mathrm{Cl}^{-}, \mathrm{SO}_{4}{ }^{2-}, \mathrm{Na}^{+}, \mathrm{Mg}^{2+}, \mathrm{Ca}^{2+}$ and $\mathrm{HCO}_{3}{ }^{-}$) points to a common origin, likely from dissolution of limestone, gypsum-rich sediments (Vega et al., 1998) and dolomite.

Some wells have problems for water consumption due their high salinity $\left(\mathrm{SO}_{4}{ }^{2-}, \mathrm{Cl}^{-}\right)$, anthropogenic contamination $\left(\mathrm{NO}_{3}{ }^{-}\right)$and geogenic contamination (As) because they exceed the WHO and NB-512 guidelines (Table 5). As seen in Table 5, SW is not an alternative for water consumption due to As and Fe concentrations (Pallina River) are above the WHO and NB-512 guidelines, SW has a elevated content of material in suspension, and probably has bacteriological contamination too, especially in the Pallina River and after the confluence of the Pallina River and the Katari River. There is evident dilution effect in almost all values measured after the confluence of both rivers with exception of $\mathrm{SO}_{4}{ }^{2-}$ and $\mathrm{Ca}^{2+}$.

The spatial distribution of As has apparently a trend of increasing concentration in the wells close to the Titicaca Minor Lake. This is the case of Huacullani, Chojasivi and Lacaya that have minor water level
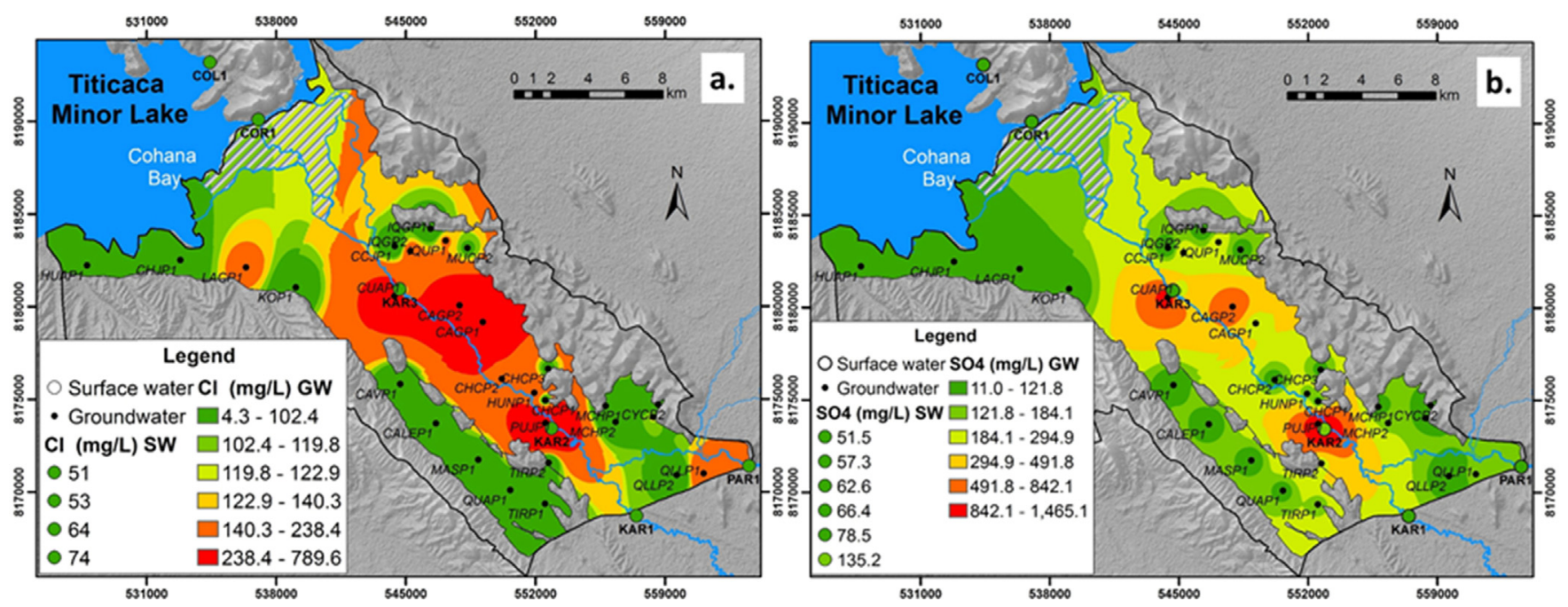

Fig. 8. Spatial distribution of concentrations: $\mathrm{Cl}^{-}$(a), $\mathrm{SO}_{4}{ }^{2-}$ (b) in $\mathrm{GW}$ and $\mathrm{SW}$, with (GIC) method (Esri, 2008). 


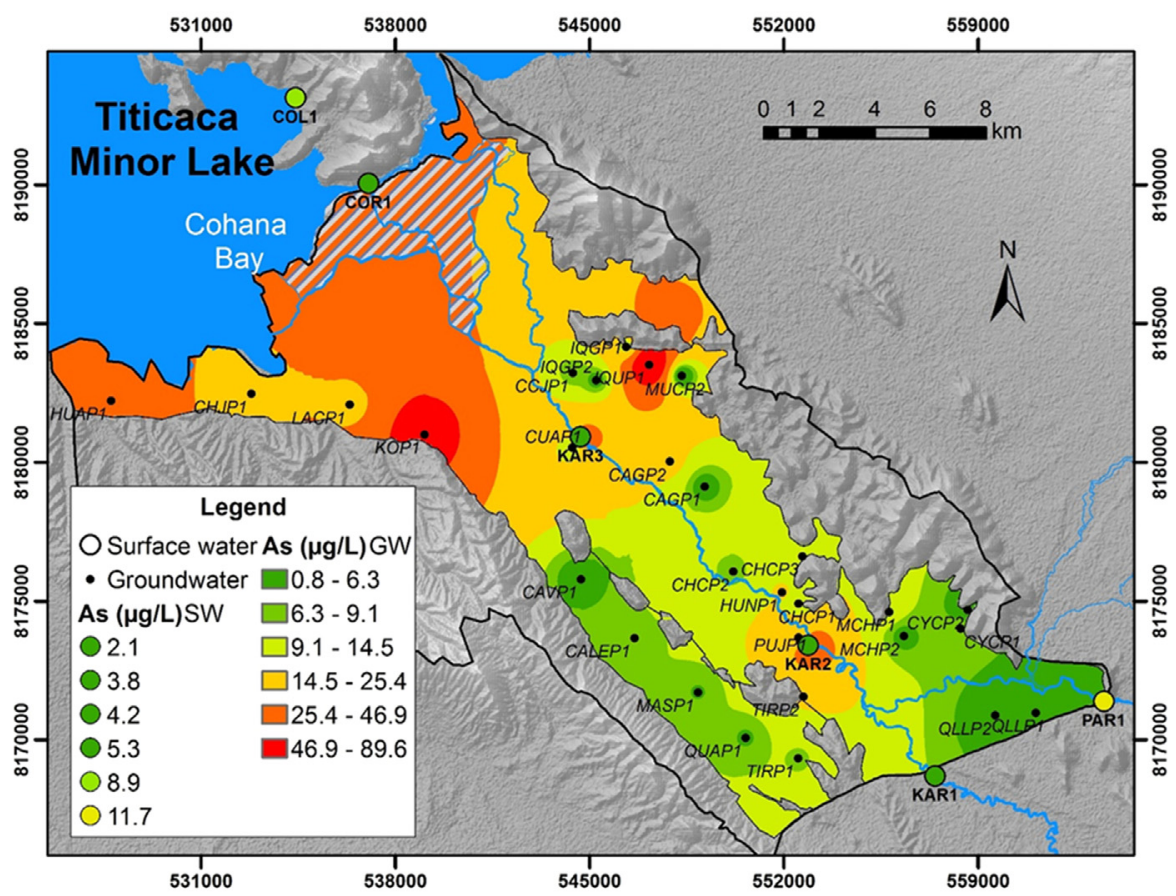

Fig. 9. Spatial distribution of As in GW, surface water SW, with (GIC) method (Esri, 2008).

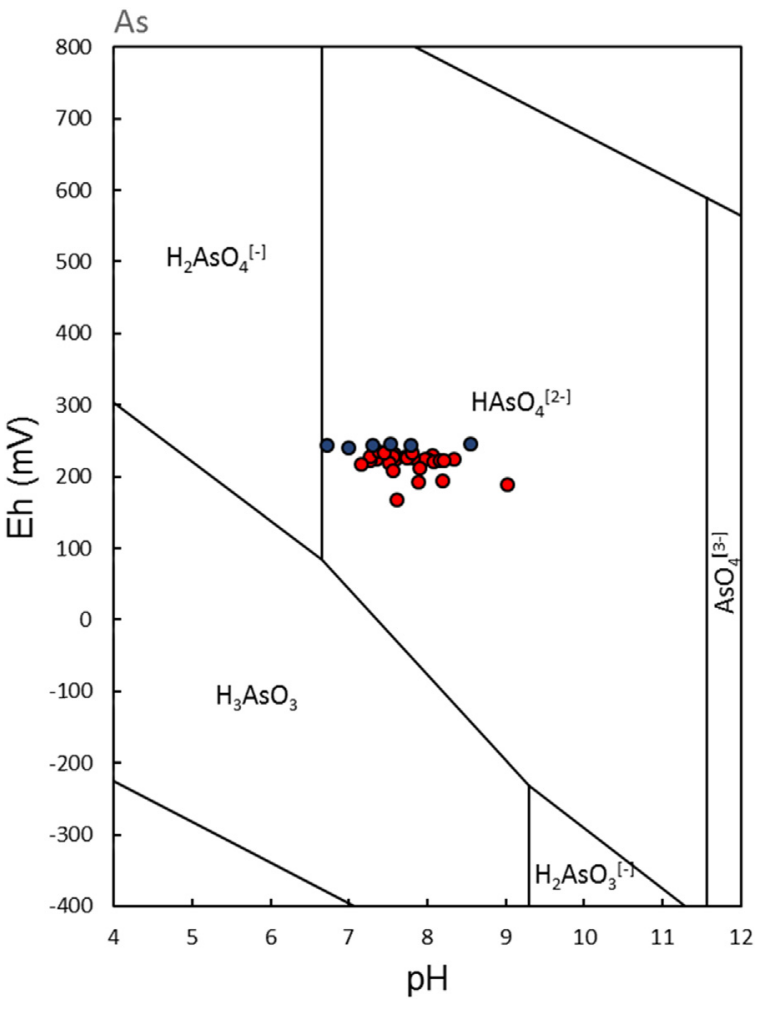

Fig. 10. The $\mathrm{pH}$ and Eh values for SW (blue) and GW (red) samples plotted in the Eh-pH diagram of aqueous As species in water at $25^{\circ} \mathrm{C}$ and $1 \mathrm{~atm}$ for the systems As-O-H (modified from Panagiotaras et al., 2012; Ticona, 2018).

and a mean concentration of $25.4 \mu \mathrm{g} / \mathrm{L}$. In the water of Titicaca Minor Lake in the region of the Cohana Bay, As has concentrations above WHO guidelines for drinking water (Archundia et al., 2017). Then there could be possible an interaction between SW and GW in this region.

There are also important concentrations of As in Iquiaca and Korila that have the major concentrations $(77 \mu \mathrm{g} / \mathrm{L}$, mean). The wells with major concentration of As are located around volcanic formations and the dissolution of volcanic rocks is considered the source of natural of As (Fig. 2).

The wells close to the Katari River at the center of the plain have high concentrations of As: Pujri, Iskakaspa, Tircani, Huancarmiento, Mucuna, Chacalleta and Coachijo (mean $21.5 \mu \mathrm{g} / \mathrm{L}$ ). The alluvial sediments are the predominant setting for arsenic-rich GW in many places around the world (Bhattacharya et al., 2002). Especially in some wells located in the lower terrains, some exchangeable As, that could be present in sediments, may be mobilized to GW due to increasing salinity (Ormachea et al., 2013) caused by evaporation.

Finally, the low concentrations of As in wells in elevated terrains as Chacalleta and Machacamarca (mean $11.4 \mu \mathrm{g} / \mathrm{L}$ ) could be explained due to flushing during rainy season when water flow increases and the contact time between water and sediment is reduced (Ormachea et al., 2013).

The occurrence of As could be attributed to the dissolution of volcanic rocks (tuff and interspersed lava of the Neogene period) as a source of natural contamination of GW (Ormachea et al., 2010). Pujri, and Coachijo are in the plain near to the Katari River (over deposits lacustrine), Iquiaca is surrounded of the sedimentary rocks with elevations composed of sandstone and arcilites from the Devonian period. Korila, Huacullani, Chojasivi and Lacaya are on the banks of a mountain range of the Neogene period with the presence of conglomerates, sandstones, arcilites, gypsums, marlstones, tuff (volcanic igneus rock), interspersed lava (volcanic rock) and diapirs (Fig. 2).

As and Mn (PC2) indicating a similar geochemical behavior for both elements; the two are redox sensitive elements, the As is commonly more mobile in oxidized GW occurring as oxyanion $\mathrm{H}_{2} \mathrm{AsO}_{4}^{-}$, as indicated by PHREEQC speciation (Chen et al., 2007). It highlights the presence of some TEs such as $\mathrm{Zn}, \mathrm{Cd}$ and $\mathrm{Cu}$ (PC3) that are generally present in oxidized waters (Hem, 1989; Farnham et al., 2003).

The SW in the point over Pallina River (PAR1) shows a moderate increase in the level of As. This may be due to the mobilization of As caused by the weathering of the volcanic rocks upstream, but another explanation could be the anthropogenic activities upstream. The concentrations of As decrease along the course of river downstream due to dilution by fresh and oxygenated waters from the upstream Katari River 

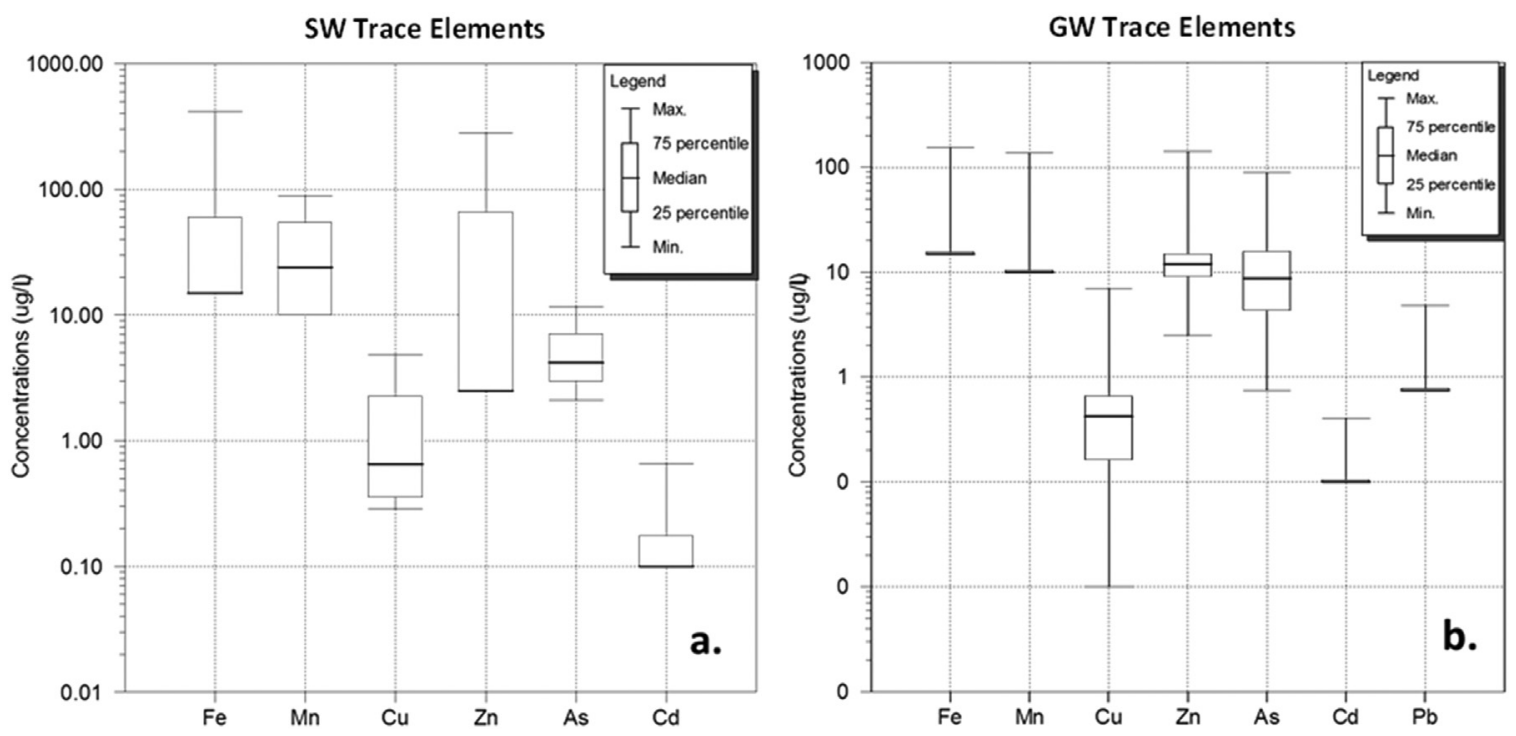

Fig. 11. Box and Whisker plot for the distribution of TEs in SW samples (a) and in GW samples (b).

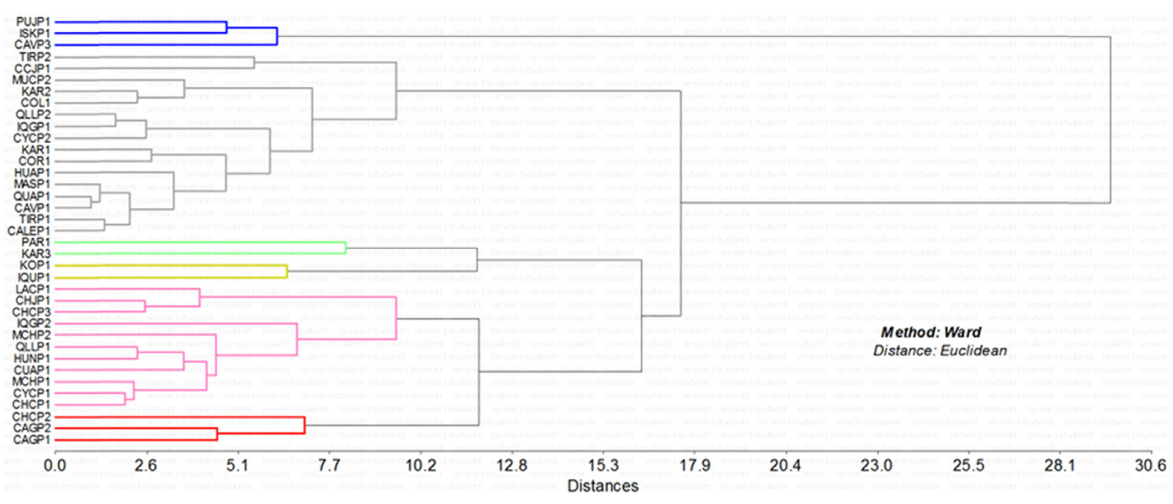

Fig. 12. Dendrogram showing the clustering of GW and SW samples (HCA), the colors represents the groups.

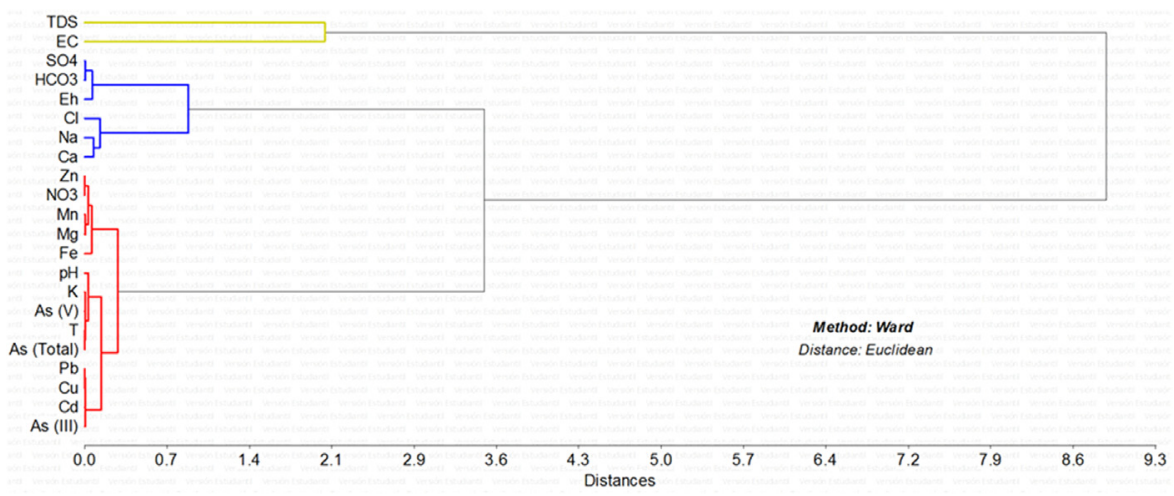

Fig. 13. Dendrogram showing the clustering of variables (HCA).

in this season (Archundia et al., 2017).

The PHREEQC hydrochemical modelling suggesting results in GW and SW (Table 4) precipitation and stability of Fe (III) phases such as goethite $[\alpha-\mathrm{FeO}(\mathrm{OH})]$ and hematite $\left[\mathrm{Fe}_{2} \mathrm{O}_{3}\right]$, and suggesting dissolution of carbonate minerals such as calcite, aragonite $\left[\mathrm{CaCO}_{3}\right]$ and dolomite $\left[\mathrm{CaMg}\left(\mathrm{CO}_{3}\right)_{2}\right]$.

The adsorption of As onto Fe oxides is a process that is controlling the mobility of As in natural waters (Bhattacharya et al., 2002), and considering the calculated saturation indices there could be adsorption of As onto surface of Fe-precipitates. This may explain that some wells have low concentration of As and there is supersaturation with respect to phases of Fe. The presence of carbonates could also affect the As levels in groundwater; the adsorption of As on calcite can be an important processes in areas with $\mathrm{pH}$ ranges of the natural environment (7-9) (Stollenwerk, 2002; Romero et al., 2004), similar to the values in the Lower Katari Basin. At this $\mathrm{pH}$ the As is found as neutral and negatively charged species such as arsenous acids $\left(\mathrm{H}_{3} \mathrm{AsO}_{3}, \mathrm{H}_{2} \mathrm{AsO}_{3}{ }^{-}\right)$, arsenic acids $\left(\mathrm{H}_{2} \mathrm{AsO}_{4}{ }^{-}, \mathrm{HAsO}_{4}{ }^{2-}\right.$ ), arsenites and arsenates (Cullen and Reimer, 1989; Romero et al., 2004). Adsorption onto mineral surfaces such as: oxyhydroxides of $\mathrm{Fe}, \mathrm{Al}$, and $\mathrm{Mn}$, clay and calcite, is the natural control for As and other metals in natural systems (Dzombak and Morel, 1990; Bowell, 1994; Van der Hoek et al., 1994; Sadiq, 1990; Carrillo 
Table 3

Principal component loadings.

\begin{tabular}{|c|c|c|c|}
\hline Variable & PC 1 & PC 2 & PC 3 \\
\hline $\mathrm{pH}$ & 0.20 & -0.12 & -0.19 \\
\hline EC & 0.99 & -0.12 & 0.06 \\
\hline Eh & -0.02 & 0.24 & 0.34 \\
\hline $\mathrm{T}$ & -0.23 & -0.05 & 0.20 \\
\hline TDS & 0.96 & -0.13 & 0.07 \\
\hline HCO3 & 0.33 & 0.12 & -0.37 \\
\hline $\mathrm{Cl}$ & 0.95 & -0.20 & 0.03 \\
\hline NO3 & -0.04 & -0.43 & -0.23 \\
\hline SO4 & 0.95 & -0.02 & 0.09 \\
\hline $\mathrm{Ca}$ & 0.61 & -0.46 & -0.2 \\
\hline $\mathrm{Mg}$ & 0.87 & -0.27 & -0.13 \\
\hline $\mathrm{K}$ & 0.01 & -0.25 & -0.26 \\
\hline $\mathrm{Na}$ & 0.95 & 0.07 & 0.10 \\
\hline $\mathrm{Cu}$ & 0.04 & 0.15 & 0.54 \\
\hline $\mathrm{Fe}$ & -0.09 & 0.43 & 0.35 \\
\hline Mn & 0.14 & 0.70 & 0.13 \\
\hline $\mathrm{Pb}$ & 0.80 & 0.06 & 0.14 \\
\hline $\mathrm{Cd}$ & 0.54 & 0.08 & 0.68 \\
\hline $\mathrm{Zn}$ & -0.09 & 0.24 & 0.74 \\
\hline As (Total) & 0.27 & 0.77 & -0.50 \\
\hline As (III) & 0.47 & 0.74 & -0.12 \\
\hline As $(V)$ & 0.22 & 0.73 & -0.55 \\
\hline Eigenvalues & 8.8 & 2.3 & 1.0 \\
\hline$\%$ Variance explained & 33 & 14 & 12 \\
\hline$\%$ Cumulative variance & 33 & 47 & 59 \\
\hline
\end{tabular}

Bold values: loadings $>|0.5|$.

and Drever, 1998; Romero et al., 2004).

\section{Conclusions}

The GW types in the study area are predominantly of the $\mathrm{Ca}-\mathrm{HCO}_{3}$; $\mathrm{Ca}-\mathrm{Cl}$ and $\mathrm{Na}-\mathrm{HCO}_{3}$, but the water types are not clearly defined; with neutral to slightly alkaline $\mathrm{pH}$, and moderately oxidizing character. More than $48 \%$ of water samples from the wells exceed the WHO and NB-512 guidelines for drinking water for As, 26\% (NB-512) and 23\% (WHO) for $\mathrm{NO}_{3}{ }^{-}, 16 \%$ (NB-512) for $\mathrm{Cl}^{-}$and $13 \%$ (NB-512) for $\mathrm{SO}_{4}{ }^{2-}$. The high concentration of $\mathrm{NO}_{3}{ }^{-}$in the wells of the villages results from anthropogenic contamination caused by domestic waste discharges.

The decreased concentration in almost all measured values after the confluence of rivers Pallina and Katari indicated a possible. The interaction between GW and SW seems to occur in the Cohana Bay region within the wells close to the lake (increased $\mathrm{NO}_{3}{ }^{-}$and As) and downstream of the Katari River (increased salinity).

Two multivariate techniques HCA and PCA were used for studying sources of dissolved species. The HCA gives less clear classification because clustering and interpretations based on the dendrograms are somehow subjective. In the contrary, the PCA, is more useful and
Table 4

Saturation indices (SI) values for selected minerals for GW and SW samples.

\begin{tabular}{|c|c|c|c|c|c|c|}
\hline Sample & Aragonite & Calcite & Dolomite & Goethite & Gypsum & Hematite \\
\hline ISKP1 & 0,19 & 0,35 & 0,36 & 4,82 & $-0,67$ & 11,58 \\
\hline PUJP1 & 0,51 & 0,66 & 0,99 & 4,42 & $-0,6$ & 10,8 \\
\hline TIRP2 & $-0,34$ & $-0,18$ & $-0,85$ & 4,37 & $-1,41$ & 10,69 \\
\hline TIRP1 & 0,17 & 0,32 & $-0,07$ & 3,91 & $-1,33$ & 9,77 \\
\hline QUAP1 & $-0,4$ & $-0,25$ & $-1,3$ & 2,76 & $-1,73$ & 7,49 \\
\hline MASP1 & 0,12 & 0,27 & 0 & 3,94 & $-1,87$ & 9,85 \\
\hline CALEP1 & $-0,29$ & $-0,14$ & $-0,81$ & 2,67 & $-1,92$ & 7,28 \\
\hline CAVP1 & $-0,31$ & $-0,16$ & $-0,9$ & 3,48 & $-2,14$ & 8,91 \\
\hline CAVP3 & 0,65 & 0,79 & 1,43 & 4,48 & $-0,6$ & 10,94 \\
\hline CUAP1 & 0,54 & 0,7 & 0,75 & 3,96 & $-1,84$ & 9,87 \\
\hline KOP1 & 0,48 & 0,63 & 0,95 & 6,64 & $-2,6$ & 15,23 \\
\hline CYCP1 & 0,5 & 0,66 & 0,6 & 3,76 & $-1,41$ & 9,47 \\
\hline СYCP2 & 0,01 & 0,16 & $-0,05$ & 4,98 & $-2,11$ & 11,92 \\
\hline MCHP1 & 0,28 & 0,43 & 0,52 & 3,75 & $-2,05$ & 9,44 \\
\hline MCHP2 & $-0,11$ & 0,04 & $-0,15$ & 2,69 & $-1,47$ & 7,34 \\
\hline CHCP1 & 0,34 & 0,49 & 0,49 & 4,09 & $-1,74$ & 10,14 \\
\hline СНCP3 & 0,13 & 0,28 & 0 & 3,3 & $-1,66$ & 8,56 \\
\hline СHCP2 & 0,73 & 0,88 & 1,07 & 4,95 & $-1,51$ & 11,84 \\
\hline HUNP1 & 0,56 & 0,71 & 1,05 & 4,21 & $-1,3$ & 10,37 \\
\hline CAGP1 & 0,04 & 0,2 & $-0,34$ & 2,38 & $-0,88$ & 6,71 \\
\hline CAGP2 & 0,92 & 1,07 & 1,55 & 5 & $-0,39$ & 11,95 \\
\hline MUCP2 & $-0,35$ & $-0,21$ & $-0,8$ & 2,97 & $-1,71$ & 7,94 \\
\hline IQUP1 & $-0,25$ & $-0,1$ & $-0,37$ & 2,69 & $-1,38$ & 7,33 \\
\hline QLLP1 & 0,38 & 0,53 & 0,49 & 3,03 & $-1,28$ & 8,01 \\
\hline QLLP2 & 0,05 & 0,2 & 0,16 & 5,24 & $-2,29$ & 12,43 \\
\hline LACP1 & $-0,31$ & $-0,16$ & $-0,85$ & 2,17 & $-1,58$ & 6,3 \\
\hline CHJP1 & $-0,29$ & $-0,14$ & $-0,71$ & 3,43 & $-2,11$ & 8,82 \\
\hline HUAP1 & $-0,68$ & $-0,53$ & $-1,93$ & 3,17 & $-2,73$ & 8,31 \\
\hline IQGP1 & 0,1 & 0,25 & $-0,21$ & 4,34 & $-2,33$ & 10,64 \\
\hline IQGP2 & 0,16 & 0,31 & 0,27 & 3,34 & $-1,18$ & 8,63 \\
\hline CCJP1 & 0,89 & 1,03 & 2,11 & 6,8 & $-2,57$ & 15,58 \\
\hline PAR1 & $-1,03$ & $-0,88$ & $-2,25$ & 3,26 & $-1,98$ & 8,47 \\
\hline KAR1 & $-0,59$ & $-0,44$ & $-1,26$ & 2,7 & $-1,96$ & 7,35 \\
\hline KAR2 & $-0,19$ & $-0,04$ & $-0,45$ & 5,01 & $-1,65$ & 12,01 \\
\hline KAR3 & $-0,72$ & $-0,57$ & $-1,33$ & 3,85 & $-2,3$ & 9,65 \\
\hline COR1 & $-1,61$ & $-1,45$ & $-3,21$ & 0,87 & $-2,03$ & 3,7 \\
\hline COL1 & 0,43 & 0,58 & 1 & 6,47 & $-2,11$ & 14,9 \\
\hline
\end{tabular}

provides more information about processes controlling the hydrochemistry.

The villages that are close to the Katari River, especially at the East side of the river, suffer of severe drinking water scarcity (Iskacaspa, Pujri, Quellani, Iquiaca, Coachijo, Caje, Iquiaca and Mucuna), and the water resources in the area are impacted by the presence of high As, $\mathrm{NO}_{3}{ }^{-}$, and high salinity levels.

According to the geochemical PHREEQC modelling results, the saturation indices indicate that As could be associated with Fe oxides and hydroxides, which are probably the most important adsorbents of As in the sediments, but the calcite or aragonite can be important for As.

The As concentrations are highest in wells close to the Titicaca

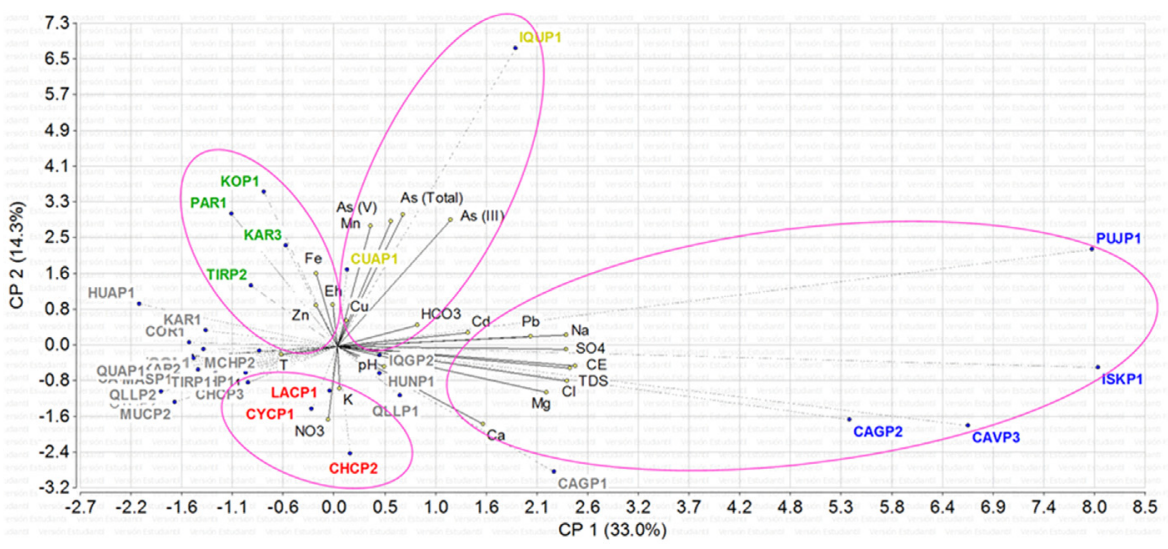

Fig. 14. Bivariate plot of PC1 and PC2 with observations and variables together (PCA). 
Table 5

Percentage of samples above the guide values of WHO and NB-512 (GW and SW).

\begin{tabular}{lllll}
\hline Parameter & $\begin{array}{l}\text { NB-512 } \\
\text { limit }\end{array}$ & $\begin{array}{l}\text { \% samples above } \\
\text { NB-512 limit }\end{array}$ & $\begin{array}{l}\text { WHO } \\
\text { limit }\end{array}$ & $\begin{array}{l}\text { \% samples above } \\
\text { WHO limit }\end{array}$ \\
\hline $\boldsymbol{G W}(\mathrm{n}=31)$ & & & & \\
$\mathrm{EC}(\mu \mathrm{S} / \mathrm{cm})$ & 1500 & 19 & & \\
$\mathrm{Cl}^{-}(\mathrm{mg} / \mathrm{L})$ & 250 & 16 & 50 & 23 \\
$\mathrm{NO}_{3}^{-}(\mathrm{mg} / \mathrm{L})$ & 45 & 26 & & \\
$\mathrm{SO}_{4}^{2-}(\mathrm{mg} / \mathrm{L})$ & 400 & 13 & & \\
$\mathrm{Ca}^{2+}(\mathrm{mg} / \mathrm{L})$ & 200 & 10 & 400 & 0 \\
$\mathrm{Mn}(\mu \mathrm{g} / \mathrm{L})$ & 100 & 3 & 10 & 48 \\
$\mathrm{As}(\mu \mathrm{g} / \mathrm{L})$ & 10 & 48 & & \\
$S W(\mathrm{n}=6)$ & & & & \\
$\mathrm{Fe}(\mu \mathrm{g} / \mathrm{L})$ & 300 & 17 & 10 & 17 \\
$\mathrm{As}(\mu \mathrm{g} / \mathrm{L})$ & 10 & 17 & & \\
\hline
\end{tabular}

Minor Lake in the Cohana Bay region, and also in wells around the volcanic formations and in wells close to the Katari River at the center of the plain. The principal source of As could be the alteration of volcanic rocks. In lower terrains, the As could be concentrated in GW due to increasing salinity caused by evaporation. The spatial distribution of As concentrations is variable in the study area; this could be explained by the variability in geological characteristics. The As sources could be geological rocks and the surface (Titicaca Minor Lake) and groundwater interaction; it could be solved by better understanding of the flow pattern. The continual monitoring of wells, increasing the number of sampling points, study of the river sediments, the installation of piezometers and their monitoring are required for better understanding of the spatial distribution and mobilization of As in this area.

\section{Acknowledgements}

The financial support of this research by the Swedish International Development Cooperation Agency (Sida Contribution: 75000553) is gratefully acknowledged. We thank to Stéphane Guédron and Celin Duwig at the Institute of Research for Development (IRD) - Bolivia for their analytical support and technical assistance. We extend our sincere appreciation to Efrain Blanco and Edson Chalco at the Chemical Research Institute, Universidad Mayor de San Andres for field work as well as Hermenegildo Fernandez for field support.

\section{References}

Appelo, C.A.J., Postma, D., 2005. Geochemistry, Groundwater and Pollution, Second ed. A.A. Balkema Publishers, Amsterdam.

Archundia, D., Duwig, C., Lehembre, F., Chiron, S., Morel, M.-C., Prado, B., BourdatDeschamps, M., Vince, E., Flores Aviles, G., Martins, J.M.F., 2016. Antibiotic pollution in the Katari subcatchment of the Titicaca Lake: major transformation products and occurrence of resistance genes. Sci. Total Environ. 576 (2017), 671-682.

Archundia, D., Duwig, C., Spadini, L., Uzu, G., Guedron, S., Morel, M., Cortez, R., Ramos, O., Chincheros, Martins, J.M.F., 2017. How uncontrolled urban expansion increases the contamination of the Titicaca Lake Basin (El Alto, La Paz, Bolivia). Water Air Soil Pollut. 228, 44.

Argollo, J., Mourguiart, P., 2000. Late quaternary climate history of the Bolivian. Altiplano. Quat. Int. 72, 37-51.

ALT (Autoridad Binacional del Sistema Hídrico TDPS), 2017. Observatorio Binacional Titicaca V.01. 〈http://www.observatoriotiticaca.org/web/〉.

ALT (Autoridad Binacional del Sistema Hídrico TDPS), 2005. Diagnóstico del nivel de contaminación de los recursos hídricos del Lago Titicaca. 〈http://www.altperubolivia.org/web_lago/WEB_LT/Finales/2_carac_fisicas/carac.htm〉.

Balzarini, M.G., Gonzalez, L., Tablada, M., Casanoves, F., Di Rienzo, J.A., Robledo, C.W., 2008. Manual del Usuario. Editorial Brujas, Córdoba, Argentina.

Bhattacharya, A., Routh, J., Gunnar, Jacks, Bhattacharya, P., Morth, M., 2006a. Environmental assessment of abandoned mine tailings in Adak, Vasterbotten district (northern Sweden). Appl. Geochem 21, 1760-1780.

Bhattacharya, P., Jacks, G., Ahmed, K.M., Khan, A.A., Routh, J., 2002. Arsenic in groundwater of the Bengal Delta Plain Aquifers in Bangladesh. Bull. Environ. Contam. Toxicol. 69 (4), 538-545.

Bowell, R.J., 1994. Sorption of arsenic by iron oxides and oxyhydroxides in soils. Appl. Geochem. 9, 279-286.

Bundschuh, J., Farias, B., Martin, R., Storniolo, A., Bhattacharya, P., Cortes, J., Bonorino, G., Albouy, R., 2004. Groundwater arsenic in the Chaco-Pampean Plain, Argentina: case study from Robles County, Santiago del Estero Province. Appl. Geochem 19, 231-243.

Carrillo, A., Drever, J.I., 1998. Adsorption of arsenic by natural aquifer material in the San Antonio-El Triunfo mining area, Baja California, México. Environ. Geol. 35, 251-257.

Chen, K., Jiao, J., Huang, J., Huang, R., 2007. Multivariate statistical evaluation of trace elements in groundwater in a coastal area in Shenzhen, China. Environ. Pollut. 147, 771-780.

Chiron, S., Duwig, C., 2016. Biotic nitrosation of diclofenac in a soil aquifer system (Katari watershed, Bolivia). Sci. Total Environ. 565, 473-480.

Chudnoff, S.M., 2006. A Water Quality Assessment of the Río Katari River and its Principle Tributaries, Bolivia (B.S. Earth and Environmental Science - Geology Option). New Mexico Institute of Mining and Technology, pp. 64-65.

Coudrain-Ribstein, A., Pratx, B., Quintanilla, J., Zuppi, G.M., Cahuaya, D., 1995a. In: Ribstein, P., Francou, B., Coudrain-Ribstein, A., Mour-guiart, P. (Eds.), Salinity of the groundwater on the Central Altiplano 24. Bulletin de l' Institut Français d'Études Andines, pp. 483-493.

Coudrain-Ribstein, A., Olive, P., Quintanilla, J., Sondag, F., Cahuaya, D., 1995b. Salinity and isotopic dynamics of the groundwater resources on the Bolivian Altiplano. In: Proceedings of the Vienna Symposium at the Application of tracers in ar-id zone hydrology. IAHS Publ. 232.

Cullen, W.R., Reimer, K.J., 1989. Arsenic speciation in the environment. Chem. Rev. 89, 713-764.

Duwig, C., Archundia, D., Lehembre, F., Spadini, L., Morel, M.C., Uzu, G., Chincheros, J., Cortez, R., Martins, J.M.F., 2014. Impacts of anthropogenic activities on the contamination of a sub watershed of Lake Titicaca. Are antibiotics a concern in the Bolivian Altiplano? Procedia Earth Planet. Sci. 10, 370-375.

Dzombak, D.A., Morel, F.M., 1990. Surface Complexation Modeling (Hydrous Ferric Oxide). Wiley Interscience, New York.

Esri, 2008. ArcGIS Desktop: 〈http://webhelp.esri.com/arcgisdesktop/9.2/index.cfm? TopicName $=$ Classification_methods $\rangle$.

Farnham, I., Singh, A., Stetzenbach, K., Johannesson, K., 2002. Treatment of nondetects in multivariate analysis of groundwater geochemistry data. Chemom. Intell. Lab. Syst. 60, 265-281.

Farnham, I.M., Johannesson, K.H., Singh, A.K., Hodge, V.F., Stetzenbach, K.J., 2003. Factor analytical approaches for evaluating groundwater trace element chemistry data. Anal. Chim. Acta 490, 123-138.

Fornari, M., Risacher, F., Féraud, G., 2001. Dating of paleolakes in the central Altiplano of Bolivia. Paleogeogr. Paleoclimatol. Paleoecol. 172, 269-282.

Giménez-Forcada, E., 2010. Dynamic of sea water interface using hydrochemical facies evolution diagram. Ground Water 48 (2), 212-216.

Guler, C., Thyne, G.D., McCray, J.E., Turner, A.K., 2002. Evaluation of graphical and multivariate statistical methods for classification of water chemistry data. Hydro Hydrogeol. J. 10, 455-474.

Hem, J.D., 1989. U.S. Geological Survey Water-Supply Paper 2254, p. 263.

Instituto Nacional de Estadística (INE), 2017. Census 2012.

IIS (Instituto de Ingeniería Sanitaria y Ambiental), 2013. Valoración de metales pesados en la cuenca del río Katari y su impacto en la calidad de vida del área de influencia. Proyecto IDH - UMSA Valoración de metales pesados en la cuenca del Río Katari y su impacto en la calidad de vida del área de influencia.

Kaiser, H.F., 1960. The application of electronic computers to factor analysis. Educ. Psychol. Meas. 20, 141-151.

Martinez, I., Zuleta, R., Pacheco, A., Sanjines, J., 2004. Co-operation on the Lake Titicaca. UNESCO, IHP, WWAP. IHP-VI. Technical Documents in Hydrology. PC - CP series. $\mathrm{N}^{\circ} 32$.

Meng, X., Korfiatis, G.P., Christodoulatos, C., Bang, S., 2001. Treatment of arsenic in Bangladesh well water using a household co-precipitation and filtration system. Water Res. 35 (12), 2805-2810.

Minchin, J., 1882. Notes on a journey through part of the Andean table land of Bolivia. Proc. R. Geogr. Soc. 4, 67.

Ministerio de Medio Ambiente y Agua (MMAyA), 2010. Plan Director de la Cuenca Katari. La Paz, Bolivia.

Ormachea, M., Blanco, E., Ramos, O., Quintanilla, J., Bhattacharya, P., Thunvik, R., Jacks, G., Taquichiri, L., 2010. Arsenic occurrence in thermal springs of the Central Bolivian Altiplano. In: Arsenic in Geosphere and Human Diseases, pp. 520-522.

Ormachea, M., Wern, H., Johnsson, F., Bhattacharya, P., Sracek, O., Thunvik, R., Quintanilla, J., Bundschuh, J., 2013. Geogenic arsenic and other trace elements in the shallow hydrogeologic system of Southern Poopó Basin, Bolivian Altiplano. J. Hazard. Mater. 262, 924-940.

ORSTOM, 1991. Institut Francais de recherche scientifique pour le développement en cooperation. EL LAGO TITICACA Síntesis del Conocimiento Inmunológico Actual.

Panagiotaras, D., Panagopoulos, G., Papoulis, D., Avramidis, P., 2012. Arsenic geochemistry in groundwater system. In: Panagiotaras, D. (Ed.), Geochemistry-Earth's System Processes. InTech, pp. 27-38.

Parkhurst, D.L., Appelo, C.A.J., 1999. User's guide to PHREEQC (Version 2) a computer program for speciation, batch-reaction, one-dimensional transport, and inverse geochemical calculations. Report of investigation, US Geological Survey and Water Resources 99-4259, p. 312.

Ramos Ramos, O.E., Cáceres, L.F., Ormachea, M.R., Bhattacharya, P., Quino, I., Quintanilla, J., Sracek, O., Thunvik, R., Bundschuh, J., García, M., 2012. Sources and behavior of arsenic and trace elements in groundwater and surface water in the Poopó Lake Basin, Bolivian Altiplano. Environ. Earth Sci. 66 (3), 793-807.

Ramos Ramos, O.E., Rötting, T., French, M., Sracek, O., Bundschuh, J., Quintanilla, J., Bhattacharya, P., 2014. Geochemical processes controlling mobilization of arsenic and trace elements in shallow aquifers and surface waters in the Antequera and Poopó mining regions, Bolivian Altiplano. J. Hydrol. 518, 421-433. 
Ravenscroft, P., Mcarthur, J.M., 2004. Mechanism of regional enrichment of groundwater by boron, USA. Appl. Geochem 19, 1413-1430.

Ribera, M., 2008. La Hiper-Contaminación de la Bahía de Cohana. La Paz, Bolivia, LIDEMA.

Ribera, M., 2010. La Bahía de Cohana. Actualización 2009-2010, La Paz Bolivia, LIDEMA.

Romero, F.M., Armienta, M.A., Carrillo-Chavez, A., 2004. Arsenic sorption by carbonaterich aquifer material, a control on arsenic mobility at Zimapán, México. Arch. Environ. Contam. Toxicol. 47, 1-13.

Sadiq, M., 1990. Arsenic chemistry in marine environments: a comparison between theoretical and field observations. Mar. Chem. 31, 285-297.

Salvarredy-Aranguren, M.M., Probst, A., Roulet, M., Isaure, M.-P., 2008. Contamination of surface waters by mining wastes in the Milluni Valley (Cordillera Real, Bolivia): mineralogical and hydrological influences. Appl. Geochem. 23, 1299-1324.

Servant-Vildary, S., Mello e Sousa, S.H., 1993. Palaeohydrology of the quaternary saline Lake Ballivian (southern Bolivian Altiplano) based on diatom studies. Int. J. Salt Lake
Res. 2, 69-85.

Stollenwerk, K.G., 2002. Geochemical processes controlling transport of arsenic in groundwater: a review of adsorption. In: Welch, A.H., Stollenwerk, K.G. (Eds.), Arsenic in Ground Water: Geochemistry and Occurrence. Seacaucus, New Jersey, pp. 67-100.

Ticona, J., 2018. Eh-pH Graficador v18.jtb.

Van der Hoek, E., Bonouvrie, P., Comans, N., 1994. Sorption of As and Se on mineral components of fly ash: relevance for leaching process. Appl. Geochem. 9, 403-412.

Vega, M., Pardo, R., Barrado, E., Deban, L., 1998. Assessment of seasonal and polluting effects on the quality of river water by exploratory data analysis. Water Res. 32, 3581-3592.

Yidana, S., Ophori, O., Banoeng-Yakubo, B., 2008. A multivariate statistical analysis of surface water chemistry data - the Ankobra Basin, Ghana. J. Environ. Manag. 86, 80-87. 